\title{
In Vitro and In Vivo Pharmacological Models to Assess Demyelination and Remyelination
}

\author{
Jean E Merrilı ${ }^{\star, 1}$ \\ ${ }^{1}$ CNS Division, Neurology Section, Sanofi-Aventis, Bridgewater, NJ, USA
}

\begin{abstract}
In making a selection of cellular tools and animal models for generating screening assays in the search for new drugs, one needs to take into consideration the practicality of their use in the drug discovery process. Conducting high-throughput primary screens using libraries of small molecules, close to 1 million members in size, requires the generation of large numbers of cells which are easily acquired, reliably enriched, and reproducibly responsive to standard positive controls. These cells need to be similar in form and function to their counterparts in human disease. In vitro assays that can be mechanized by using robots can therefore save time and costs. In selecting in vivo models, consideration must be given to the species and strain of animal chosen, the appropriateness of the model to human disease, the extent of animal husbandry required during the in-life pharmacological assessment, the technical aspects of generating the model and harvesting the tissues for analyses, the cost of research tools in terms of time and money (demyelinating and remyelinating agents, amount of compound to be generated), and the length of time required for drug testing in the model. A consideration of the translational aspects of the in vivo model compared to those used in the clinic is also important. These themes will be developed with examples for drug discovery in the field of CNS demyelination and repair, specifically as it pertains to multiple sclerosis.

Neuropsychopharmacology Reviews (2009) 34, 55-73; doi: I0. I038/npp.2008. I45; published online 17 September 2008
\end{abstract}

Keywords: drug discovery; multiple sclerosis; remyelination; experimental autoimmune encephaloneyelitis; cuprizone model; oligodendrocyte

\section{INTRODUCTION}

Multiple sclerosis (MS) is an autoimmune disease in humans whose key pathology is demyelination and axonal loss as the result of immune cell production of proinflammatory molecules and active attack of both the myelin sheaths and the cells producing them, the oligodendrocytes. The hallmarks of the pathology are plaques which are found in myelin-rich white matter regions of the central nervous system (CNS), in both brain and spinal cord. Destruction of myelin, oligodendrocytes, and ultimately axons is mediated by activated $\mathrm{T}$ cells, autoantibodies directed at self-antigens, enzymes, and free radicals secreted by macrophages and microglia (Prineas et al, 1984; Raine and $\mathrm{Wu}, 1993)$. Oligodendrocyte progenitors reside throughout the CNS from birth well into old age in the human brain (Roy et al, 1999; Nunes et al, 2003). It has been well documented that these cells are activated by the CNS pathology in MS to migrate to the lesion sites and

${ }^{*}$ Correspondence: Dr JE Merrill, CNS Division, Neurology Section, Sanofiaventis, Route 202-206, Bridgewater, NJ 8807, USA, Tel.: + 908-2312348, Fax: + 908-231-2413, E-mail: jean.merrill@sanofi-aventis.com Received 14 March 2008; revised 18 July 2008; accepted 3 August 2008 attempt to repair the damage by differentiating and remyelinating naked axons (Prineas and Connell, 1979; Prineas et al, 1984, 1989, 1993; Raine and Wu, 1993; Lassmann et al, 1997). This continuum of myelin breakdown and repair can be seen in the majority of lesions in MS tissues and has led to the exploration of the process of repair in the CNS using basic models of demyelination and remyelination in vitro and in modeling these events in animals. The understanding that remyelination recapitulates processes known to occur in primary myelination, the growing knowledge of the local environmental factors that cause demyelination or prevent/promote remyelination, and the recognition that through the use of small molecules and biologics pharmacological intervention might harness the endogenous repair process to treat MS will be explored in this chapter (Sim et al, 2002, 2006; Franklin and Blakemore, 1995; Blakemore and Franklin, 1991). Specifically, a focus on which tools lend themselves to the drug discovery process and bridge the gap between models and man will be addressed.

Such a large area of research using experimental models cannot be covered in its entirety. This chapter is not intended to be a thorough review of the literature from the 
initial description through contemporary papers on all the models in vitro and in vivo for demyelination and remyelination. It will not review every dosing regimen, explore every variation on disease induction paradigms in the models, or argue fine points about exceptional pathology that can be elicited in a given model. In many cases and especially when the current general use of models has not deviated in a major way from the original description, the original references are cited. This chapter is also not intended to go beyond preclinical efficacy studies and the usefulness of models for such a purpose. Therefore, the issues surrounding clinical trials and the ideal drug candidate are outside the realm of the chapter. Neither the pros and cons of therapeutic modalities (in models or man) nor safety studies in in vivo models were intended to be a part of the discussion on use of models for evaluating the effectiveness of drugs. Nevertheless, some examples of drugs currently in clinical trials and their use in these models will be discussed with respect to some of the hurdles in assessing remyelination in the clinic.

\section{IN VITRO: CELL SOURCES}

\section{Primary Cultures: Rodent}

Primary rodent culture systems lend themselves to evaluating oligodendrocytes at different stages of differentiation within the committed lineage (McCarthy and deVellis, 1980). The proliferative, migratory, bipolar oligodendrocyte precursor in rats can be identified by monoclonal antibodies to gangliosides GD3 and A2B5; such cells are also positive for platelet-derived growth factor- $\alpha$ receptor $(\mathrm{PDGF} \alpha \mathrm{R}+)$ and express, among others, such transcription factors as Olig1 and 2, id2, POU III, Sox 11, Krox 24 (Pfeiffer et al, 1993; Nicolay et al, 2007). Prooligodendrocytes are multipolar, postmigratory, proliferative cells identified by 04 antibody to the sulfated surface antigen POA; Sox 10 and 17, and Mash 1 are transcription factors seen at this stage. Premyelin oligodendrocytes express galactocerebroside (GalC), sulfatide, and $2^{\prime}-3^{\prime}$-cyclic nucleotide $3^{\prime}$-phosphohydrolase (CNP) as detected by anti-GalC (01), anti-sulfatide (04), and anti-CNP antibodies, respectively. Cells at this stage express complex branching with secondary and tertiary processes. Mature myelin-producing oligodendrocytes can be identified by antibodies to myelin basic protein (MBP), proteolipid protein (PLP), and myelin oligodendrocyte glycoprotein (MOG). Complex myelin sheaths are readily seen and the transcription factor $\mathrm{Nkx} 2.2$ can be detected at this stage. Reverse transcriptase (RT)-PCR or microfluidics cards can be used to identify mRNA signatures for receptors, myelin genes, and transcriptions factors. Antibodies to astrocytes (anti-glial fibrillary acidic protein, GFAP) and microglia (CD11b, ED1 (rat), F4/80 (mouse)) are typically used in these cultures to detect potential contaminating cells types.

\section{Primary Cultures: Human}

Human fetal oligodendrocyte precursors are obtained from postmortem human fetal spinal cord or brain (18-23 weeks of gestation). Enrichment of up to $90 \%$ is achieved by separation on immunomagnetic microbeads coated with rat anti-mouse IgM that captures the progenitors that have been labeled with A2B5 antibody. Separation by differential adherence properties followed by growth in oligodendrocyte-enhancing N1 or N2B3 medium for 5-10 days and plating on poly-L-lysine-coated plates can yield up to approximately $80 \%$ enrichment for A2B5 + cells (Miron et al, 2007, 2008; Wilson et al, 2003; Zhang et al, 2006). PDGF $\alpha$ R can also be used to validate enrichment. Human adult preoligodendrocytes can be procured from surgical resections or biopsies of subcortical white matter from temporal lobe obtained from medication-refractory epilepsy patients. Enrichment can be achieved by differential adherence (Armstrong et al, 1992), magnetic activated cell sorting using A2B5 antibody as with fetal cells (Sim et al, 2006), or by differential density separation using a $30 \%$ Percoll gradient (Miron et al, 2007). As in rodent cultures, antibodies to $\beta$-tubulin ( $\beta$ TubIII), neurofilament (NF), and microtubule associated-protein 2 (MAP2) are used to demonstrate the lack of neuronal contamination. Although these cultures are highly enriched, A2B5 is a marker of neural stem cells and not a guarantee that all the cells in the culture will be driven down the oligodendrocyte lineage. In addition, the numbers of cells generated from adult tissues is usually under a million cells from any given tissue preparation, greatly limiting their use in transcript profiling or assessing compounds in vitro (Sim et al, 2006). Assays used to demonstrate differentiation of these cells usually quantitate expression of markers at earlier stages (04) or resort to image-based analysis of increased process arborization.

\section{CONCLUSIONS}

Primary cultures of rodent oligodendrocyte progenitors harvested from neonatal animals are the most widely used in vitro for modeling demyelination and remyelination. This is because such cultures generate easily purified cells in large enough numbers for medium throughput primary and secondary screens. Such primary screens might constitute up to tens of thousands of compounds whereas secondary screens could involve hundreds of compounds. Rodent oligodendrocytes prepared from 1- to 2-day-old neonates generate cell targets that are identical and reproducible from experiment to experiment. There are adequate similarities between rodent and human cells in the differentiation and myelination processes for rodent cells to be of value in searching for drugs for the treatment of human disease.

Tissues from which adult human oligodendrocytes or fetal human progenitors can be derived may be more difficult to obtain on a regular and consistent basis. Human 
cells are more difficult than rodent cells to acquire in large and enriched enough numbers for primary screens. The acquisition of cells from adult epilepsy tissues derived from different regions of brain with varying degrees of pathology, generate cell populations of variable purity. Fetal tissues may be of varying gestational stages. In contrast to rodent oligodendrocyte precursors, human oligodendrocyte precursors are not easily driven in vitro to express MBP, often having to be kept in culture for several weeks. Nevertheless, when the number of compounds to assess is below a hundred, human cells can be generated in adequate numbers for orthologue validation assays of compounds originally selected from primary rodent library screens.

\section{Cell Lines}

The spontaneous generation of a permanent cell line resembling an oligodendrocyte-type 2 astrocyte (O-2A) precursor from cultures of neonatal rat cerebral cortex gave rise to the bipotential cell line, CG4. When grown in PDGF and basic fibroblast growth factor (bFGF), CG4 cells proliferate. Removal of growth factors leads to differentiation of these cells within $48 \mathrm{~h}$ into oligodendrocytes that eventually stain positively for MBP. Transfer of the line into $10 \%$ fetal calf serum (FCS) causes the line to differentiate into astrocytes (Louis et al, 1992). The spontaneous differentiation of this line needs to be kept at a basal level to provide a window for agents to drive differentiation. CG4 cells are also useful for assessing agents that induce and interfere with excitotoxicity and cell death (CasacciaBonnefil et al, 1996; Brogi et al, 1997; Yoshioka et al, 1998).

Immortalized oligodendrocyte cell lines from mice have also been created and used for assessment of agents driving differentiation and protecting against cell death. Jensen et al (1993) produced the 6E12 line derived from the spinal cord of an MBP-SV40 large T-antigen transgenic mouse. Before their activation these cells stained minimally for 04 or GalC. After stimulation with forskolin or dibutyryl cyclic AMP (dbcAMP), these oligodendrocyte markers increased, as did PLP mRNA. However, unlike normal oligodendrocyte precursors, 6E12 cells did not demonstrate an increase in MBP mRNA or protein, most likely due to the increase of the MBP repressor tSCIP/Tst-1. Immortalized murine oligodendrocyte cell lines representing different stages of differentiation in the lineage were created in the laboratory of Anthony Campagnoni. These $\mathrm{N}$ cells were created from mouse cerebral primary cultures using the retroviral vector pZIPSVtsA58 (containing a temperature Tag gene) (Verity et al, 1993; Foster et al, 1993). Among the cell lines, the N1 cell line represented the least mature line and was shown to be the most sensitive to nitric oxide (NO)-induced mitochondrial damage and death. The N20.1 line, positive for sulfatide, GalC, CNP, and MBP mRNA, represented the most mature line and was least sensitive to cell death by NO (MacKenzie-Graham et al, 1994). These cell lines faithfully replicated the effects of free radicals seen using normal primary rodent oligodendrocytes and their progenitors (Merrill and Scolding, 1999; Casaccia-Bonnefil, 2000).

Human oligodendroglioma cell lines HOG and TC620 (Merrill and Matsushima, 1988; Kashima et al, 1993) have also been evaluated for their potential use as substitutes for the more difficult to obtain human oligodendrocyte precursors. Such tumors are rare and generally of mixed cell types. These two lines were confirmed to be oligodendrogliomas with an immature oligodendrocyte phenotype by molecular profiling. TC620 cells expressed CNP mRNA and protein and MBP-related mRNA (Kashima et al, 1993). TC620 cells behave like primary oligodendrocytes in some assays such as proliferation in response to interleukin 2 (IL2; Benveniste and Merrill, 1986; Otero and Merrill, 1997). Although these transformed lines may be of some use as human oligodendrocyte precursor surrogates, it is clear that there is a limit to their reliability as indicators of normal cell function, especially differentiation.

Conclusions. Drug discovery has been greatly aided by the use of cell lines derived from spontaneously transformed cells, genetically immortalized lines, and tumor lines. The cost- and time-effectiveness of their production and use, clonality, unlimited supply, uniform responsiveness, and similarity in function (when it exists) to normal cells have made them practical substitutes in primary screens entailing, five hundred thousand to one million compounds.

\section{Mixed and Organotypic Cultures}

Mixed glial neuronal cultures that produce myelinated axons can be established from embryonic day 15 (E15) or E16 mouse or rat fetal telencephalons. After mechanical dissociation, sieving and placement in chemically defined medium, cells are either allowed to attach and grow as mixed stationary cultures (Lubetzki et al, 1993; Demerens et al, 1996) or are kept under constant rotation such that within 2 days, they form aggregates of glia and neurons (Tosic et al, 1992; Copelman et al, 2000). In BottensteinSato medium supplemented with $\mathrm{PDGF}_{\mathrm{AA}}$, embryonic murine-mixed stationary cultures give rise to myelinated axons within 2 weeks. The timing of differentiation of oligodendrocytes as determined by GalC and MBP staining and the formation of compact myelin in vitro is roughly the same as that in vivo: the first myelinating oligodendrocytes in mouse optic nerve appear at postnatal day 6 (P6) (Lubetzki et al, 1993; Demerens et al, 1996). In rotated cell suspension cultures from embryonic rat, dissociated cells form mixed aggregates within 2 days and mature to full axonal myelination in a time scale similar to the myelination that occurs in vivo (Honnegger, 1985; Loughlin et al, 1997). In yet a different mixed culture system, Murray and Dubois-Dalcq (1997) report that oligodendrocyte progenitors can be generated from tissues derived from 53 to 58 days after conception. In this model, after 2-3 weeks in vitro in Bottenstein-Sato medium, dividing neural stem cells cluster, detach from the culture dish surface, and continue 
to expand as spheres. These spheres, containing mostly multipotential, polysialated neural cell adhesion molecule $\left(\right.$ PSA-NCAM $^{+}{ }^{+}$, nestin ${ }^{+}$, mitotic neural precursors, can be passaged every 4 weeks with the generation of new spheres up to 7 months. Spheres can be frozen in 10\% DMSO. Withdrawal of mitogens permits development of $04^{+}$cells to differentiate and express GalC and PLP/DM20.

Myelinating cultures can also be produced by mixing together purified populations of neurons and oligodendrocyte progenitors that have been separately prepared. The source of neurons is usually murine dorsal root ganglia (DRG) neurons isolated from E 13.5-14.5 whereas the oligodendrocyte progenitors may be derived from mouse or rat postnatal day 1 cerebral cortices (McCarthy and deVellis, 1980). DRG cultures are exposed to fluorodeoxyuridine (FUDR) to inhibit mitoses of nonneuronal cells for up to 4 days and cultured up to 4 weeks before addition of enriched oligodendrocyte progenitors (Stevens et al, 2002; Zhang et al, 2006; Ishibashi et al, 2006). Oligodendrocyte precursors differentiate within a week and myelinate within 2 weeks under these conditions. Unlike embryonic mixed cultures, oligodendrocyte-neuronal cultures do not contain other glia or endothelial cells that might modulate myelinaxon interactions as well influence the effects of exogenous agents and drugs added to cultures to promote cell survival and differentiation.

Cerebellar organotypic slice cultures have also been used to examine the effects of agents on myelination. Sagittal slices $(300 \mu \mathrm{m})$ from P2 neonatal rat cerebella can be prepared using a tissue chopper. These slices can be treated with drugs or agents for up to $48 \mathrm{~h}$, followed by mechanical dissociation of single cells and analysis of these cells for differentiation (Stevens et al, 2002).

Conclusions. Mixed glial cultures are more complicated than single-cell cultures to establish and use but they can serve as an intermediate culture system for examination of demyelinating and remyelinating agents between simpler single-cell preparations and the resource-consuming in vivo models. Mixed aggregates or spheres, where oligodendrocyte precursors are a small fraction of the total cell number, can also be used to demonstrate the capacity of hormones and possibly small molecules to drive oligodendrocyte differentiation. Although the culture technique of organotypic slices allows for the preservation of the architecture of the nervous system and stimulation of complex electrical and biochemical pathways, it may not be as reproducible as single-cell or mixed-cell cultures and is a very low throughput assay system.

\section{IN VITRO MODELS AND MECHANISMS}

\section{Models}

There is evidence that myelin damage and oligodendrocyte cell death occurs in MS lesions as the result of excitotoxicity (Yoshioka et al, 1998), lack of or inappropriate growth factor signaling (Scolding and Compston, 1995), immune cell-mediated mechanisms (Merrill et al, 1993; Selmaj et al, 1991, 1992), proinflammatory cytokines (Brogi et al, 1997; Vartanian et al, 1995; Casaccia-Bonnefil, 2000), ceramide (Larocca et al, 1997; Casaccia-Bonnefil et al, 1996), enzymes (James et al, 1998), free radicals (Mitrovic et al, 1994, 1996; Husain and Juurlink, 1995), and anti-MOG antibody plus complement (Copelman et al, 2000). All of these forms of cell cytotoxicity can be recreated as in vitro assays with quantitative endpoints.

Oligodendrocyte differentiation in vitro using rodent oligodendrocyte precursors can be accomplished within 5-7 days in vitro. Transcript profiling for myelin and other differentiation-related genes ( $M B P, P L P, M A G, M O G)$ using northern blots or in situ hybridization can be performed for a minimal number of compounds whereas RT-PCR (High Throughput Genomics Technologies ArrayPlate, HTG Inc. Tucson, AZ) and microfluidics cards (TLDA; Applied Biosystems, Foster City, CA) would be more useful for higher throughput (Blanchard and Friend, 1999; Martel et al, 2002). For analysis of myelin proteins, microscopebased imaging systems to quantitate antibody fluorescence using the two-color detection LI-COR system (Odyssey Infrared Imaging System; LI-COR, Lincoln, NE) or immunohistochemical ELISA-based analyses are available. Automated morphometric analyses for image-based highcontent screening (HCS) is based on determining shapes of cells, distinguishing increased branching, and quantitating secondary and tertiary process numbers and lengths using reagents like CellMask cytoplasmic/nuclear stains (Invitrogen, Carlsbad, CA). HCS algorithms compatible with automated digital cell microimagers, data acquisition systems, and counting software can be used for analysis of single (Cellomics ArrayScan, Cellomics, Pittsburgh, PA; Fisher Biosciences, Fisher, Lafayette, CO) or multiple imaging channels (INCell 3000, Developer Toolkit; General Electric, INCell GE, Piscataway, NJ). These hardware/ software systems remove the subjectivity and time-consuming component of visualization and manual evaluation.

Differentiation of human oligodendrocyte precursors in vitro poses several distinct differences from cultures of rodent cells. Although human precursors can be driven to differentiate morphologically within 7 days in vitro, in many cases a substantial number of cells expressing MBP do not develop in vitro until 2-3 weeks later (Wilson et al, 2003). Thus, the feasibility of using assays for differentiation of human precursors is more challenging than that of rodents cells and typically involves evaluating the transition of bipolar cells to $04^{+}$or $\mathrm{CNP}^{+}$cells with intermediate to high-complexity branching of processes (Zhang et al, 2004).

It is clear that myelination is regulated by the physical contact between mature oligodendrocytes and axons and that production of compact myelin occurs only when the axon is functioning. Targeting the inhibition of abnormal expression of axon-associated molecules that block myelination may be one way of allowing myelination to proceed. This can be examined in complex cultures. Demerens et al (1996) demonstrated in mixed stationary cultures that 
myelination could be blocked by tetrodotoxin or enhanced by $\alpha$-scorpion toxin stimulation of electrical activity; the effect was confirmed in vivo using the developing optic nerve of the mouse. Electrical activity regulates the expression of cell adhesion molecules on axons such as PSA-NCAM and axonal L1 (Coman et al, 2005). In MS, PSANCAM is found on demyelinated axons in chronic lesions, but not on myelinated axons. Myelin deposition occurs only on axons that have downregulated PSA-NCAM. Internalization of PSA-NCAM by antibody or enzymatic removal of the polysialic acid moieties with endoneuraminidase increases myelination by fivefold in mixed cultures (Charles et al, 2000). Electrical stimulation of mixed cocultures stimulates ATP production which induces astrocytes in these cultures to produce leukemia inhibitory factor (LIF) (Ishibashi et al, 2006). This strong neurotrophic factor, in turn, stimulates myelin production by mature oligodendrocytes in the cultures.

In mixed co-cultures in vitro, it has been demonstrated that oligodendrocyte progenitors express functional adenosine receptors and detect action potentials from axons with large intracellular calcium fluxes. Adenosine (but not ATP) inhibits oligodendrocyte progenitor proliferation, promotes its interaction with axons, and drives myelination over the course of 14 days in vitro (Stevens et al, 2002). Myelination in these cultures systems is quantitated by counting of MBP-stained cells or the number of internodes/myelin segments, by toluidine blue staining (Wilson), and by validation of compact myelin using EM (Charles et al, 2000; Demerens et al, 1996; Stevens et al, 2002).

\section{CONCLUSIONS}

Exposure of isolated precursors or differentiated oligodendrocytes to agents that promote proliferation, migration, survival, and differentiation simplifies the interpretation of the functional outcome by providing quantifiable direct effects on the oligodendrocyte targets uninfluenced by other cells and their soluble products. For phenotypic screens with small molecule libraries (Saxe et al, 2007), desired functional outcomes like survival and differentiation can be further analyzed for gene biomarkers indicating the mechanism of drug action using affymetrix arrays, microfluidics cards, or high-throughput genomic (HTG) transcript profiling of relevant gene clusters (Sim et al, 2006). These models allow for in vitro proof of concept, the assessment of whether small molecules can penetrate cell membranes, and the examination of the efficacy of biologics such as antibodies, cytokines, neurotrophic factors. This is an important part of the screening process as some of these agents may not yet have the physical or pharmacokinetic properties which would allow them to reach pharmacodynamic exposure levels or cross an intact blood-brain barrier (BBB) in vivo.

Mixed culture systems are technically challenging and time consuming but allow for the assessment of pharma- cological parameters, the use of validating inhibitor molecules, as well as the ability to dissect mechanisms of action of drugs in more controlled and easily manipulated conditions than can be achieved in vivo.

\section{Mechanisms: Survival and Differentiation}

Cytokine and neurotrophic factors. Among the cytokines and neurotrophic factors that positively affect oligodendrocyte precursor proliferation or precursor and mature oligodendrocyte survival, maturation, and differentiation, IL2, IL11, PDGF, bFGF, LIF, neurotrophin 3 (NT3), glial growth factor-2 (GGF2, neuregulin), insulin-like growth factor-1 (IGF-1), and ciliary neurotrophic factor (CNTF) are the best-studied proteins (Marmur et al, 1998; Copelman et al, 2000; Sperber and McMorris, 2001). These agents prove to be quite useful as positive controls in assays searching for unique small molecules to perform similar functions. Cell sources are important factors in evaluating such mechanisms. In comparing human cells from fetal spinal cord with cells from adult human epilepsy temporal lobe, it has been reported that fetal cells proliferate in response to PDGF whereas adult cells do not. However, IGF1 drives differentiation of both fetal and adult precursors (Armstrong et al, 1992; Wilson et al, 2003). There have been reports that basic FGF has no effect on proliferation on either fetal or adult human cells in vitro whereas it does drive cell division in cultures of rodent precursors (Eccleston and Silberberg, 1984; Armstrong et al, 1992; Grinspan et al, 1993; Marmur et al, 1998; Wilson et al, 2003). Depending on the stimulus used, proliferation assays for progenitor cells can be established to run as an overnight assay or beyond up to 10 days in vitro with assessment using ${ }^{3} \mathrm{H}$-thymidine uptake (added in the last $17 \mathrm{~h}$ of culture), bromodeoxyuridine (BrDU) staining, CyQuant NF Proliferation Assay kit (Invitrogen) or autoradiography (Otero and Merrill, 1997; Wilson et al, 2003; Grinspan et al, 1993; Armstrong et al, 1992). Quantitative readouts like radioisotope incorporation can be achieved in a 96-well to as small as a 384-well format. When cell numbers are limiting, as in human cell cultures, cell-specific antigens can be stained and cells manually counted (Zhang et al, 2004).

Hormones. Estrogen and triiodothyronine (T3) are useful tools both in vitro and in vivo for assessing survival and differentiation of oligodendrocytes and their progenitors. Estrogen receptor $-\alpha$ and $\beta(\operatorname{ER} \alpha, \operatorname{ER} \beta)$ have been detected on primary neonatal rat and mouse oligodendrocytes and their precursors in vitro and in vivo. Double staining for immature $\left(\mathrm{A} 2 \mathrm{~B}^{+}\right)$and mature $\left(\mathrm{MBP}^{+}\right)$cells with $\mathrm{ER} \alpha$ or ER $\beta$-specific antibodies demonstrated subcellular localization in the nucleus and cytoplasm by confocal microscopy; nuclear compartmentalization became more pronounced with cell maturation (Takao et al, 2004). Although $17 \beta$ estradiol (E2) had no effects on cell proliferation, it did drive the increase in processes after 4 days in vitro at 50 $500 \mathrm{nM}$ (Zhang et al, 2004). E2 also protected immature and mature primary and CG4 cells from SIN-1 cytotoxicity at 20-200 nM. This protective mechanism required $17 \mathrm{~h}$ pretreatment with E2, as confirmed by LDH and MTT readouts, and was blocked by ICI 182780, an inhibitor 
blocking $\mathrm{ER} \alpha$ and $\operatorname{ER} \beta$ receptors (Takao et al, 2004). The SIN-1 exposure time was $6 \mathrm{~h}$ for CG 4 and $17 \mathrm{~h}$ for primary cells, thus making this assay a convenient one for functional assessment before testing into animal models. Assessment of T3 effects on aggregates or neural spheres is less straightforward but still achieveable, requiring 2-4 weeks exposure to hormone. Assays demonstrating myelin-specific transcripts and proteins, immunohistochemistry for cell surface markers of mature oligodendrocytes, and morphometry confirm maturation of oligodendrocytes in the mixed cultures (Murray and Dubois-Dalcq, 1997; Tosic et al, 1992).

Small molecules. Small molecules are useful standard tools because they can be reproducibly generated and cost less than biologics. cAMP analogues have been shown to be oligoprotective and to drive differentiation. dbcAMP or 8-bromocAMP at $1 \mathrm{mM}$, increase the number of oligodendrocytes expressing myelin components in vitro after 1 week (Raible and McMorris, 1989). cAMP-elevating agents like $10 \mu \mathrm{M}$ forskolin, $100 \mu \mathrm{M}$ dbcAMP, and PDEIV antagonists, propentofylline $(100 \mu \mathrm{M})$ and ibudilast $(100 \mu \mathrm{M})$ all prevent kainateinduced LDH release in oligodendrocyte cultures.

Recently, a small molecule currently in clinical trials for the treatment of MS has been investigated for its effect on survival and differentiation of oligodendrocytes in vitro. FTY720 is a lipophilic sphingosine-1-phosphate (S1P) analogue that crosses the BBB, currently in Phase III clinical trials for MS as an antiinflammatory agent (Kappos et al, 2006). FTY720 is an agonist of four G protein-coupled receptors S1P1, 3, 4, and 5, all members of the endothelial differentiation gene-related (Edg) family (Davis et al, 2005; Mandala et al, 2002). Different time and dose-dependent effects of S1P have been reported for rodent progenitors and mature oligodendrocytes in vitro including process retraction or cell survival (Jaillard et al, 2005). Some of the same effects are seen in human progenitors exposed to FTY720 in vitro as reported by Miron et al, (2007) such as progenitor survival following growth factor removal in 2-day cultures after exposure to $10 \mathrm{nM}$ FTY720. Nevertheless, previous studies showed that S1P could not rescue rodent preoligodendrocytes from growth factor withdrawal-induced death, suggesting differences in either relative S1P receptor levels or subtypes or associated signaling cascades between humans and rodents (Toman et al, 2004). Table 1 summarizes the benefits and liabilities of the in vitro models assays in drug discovery for modeling survival and repair.

\begin{tabular}{|c|c|c|c|c|}
\hline Cell Models & $\begin{array}{c}\text { Cell death and } \\
\text { demyelinating agents }\end{array}$ & $\begin{array}{l}\text { Survival, proliferation, migration } \\
\text { and myelin-inducing agents }\end{array}$ & Model pros & Model cons \\
\hline \multicolumn{5}{|l|}{ Primary oligodendrocytes } \\
\hline Rodent neonatal cerebra/ON & TNF $\alpha, L T, I F N \gamma, I L 1 \beta$ & dbcAMP, 8-bromo-cAMP, forskolin, & Reproducibility, large no. cells, & Prep time \\
\hline \multirow[t]{4}{*}{ oligodendrocyte progenitors } & NGF, ceramide, kainate, & FTY720,17- $\beta$-estradiol, PDE IV & cells differentiate/myelinate & \\
\hline & SNAP, SIN-1, pyrogallol & antagonist, S1P agonist, IL2, IL11, & & \\
\hline & & PDGF, bFGF, LIF, NT3, GGF2, & & \\
\hline & & IGF-1, CNTF & & \\
\hline Human fetal progenitor & NA & PDGF, IGF-1 & Human source & Starting material difficult to acquire \\
\hline & & & & and different each time, small no, cells, \\
\hline Human adult progenitor & NA & IGF-1, simvastatin, FTY720 & Human source & may differ from adult cells \\
\hline \multirow[t]{3}{*}{ Human adult mature } & NA & Simvastatin & Human source & Starting material difficult to acquire \\
\hline & & & & and different each time, small no. cells, \\
\hline & & & & difficult to enrich, don't express MBP \\
\hline \multicolumn{5}{|l|}{ Cell lines } \\
\hline \multicolumn{5}{|l|}{ Rodent } \\
\hline \multirow[t]{2}{*}{ CG4 } & Ceramide,kainate, $\mathrm{SIN}-1$ & dbcAMP, 8-bromo-cAMP, & Reproducibility, large no. cells, & Differentiate very fast \\
\hline & & retinoic acid, 17 - $\beta$-estradiol & cells differentiate/myelinate & Don't always act like primary cells \\
\hline N2 & SNAP & NA & useful in cell death models & Don't differentiate to MBP+ \\
\hline \multicolumn{5}{|l|}{ Human } \\
\hline TC620 & NA & IL2 & Immature human oligodendrocyte & Derived from tumor, don't differentiate \\
\hline HOG & NA & NA & Immature human oligodendrocyte & Derived from tumor, don't differentiate \\
\hline \multicolumn{5}{|l|}{ Mixed cultures } \\
\hline \multirow[t]{2}{*}{ Oligo-neuron } & Hypoxia & ATP, adenosine, anti-PSA-NCAM, & Cultures myelinate in 2 weeks & Complicated culture setup \\
\hline & & endoneuraminidase & & \\
\hline \multirow[t]{3}{*}{ Aggregates } & NA & T3 & Cultures myelinate in 2 weeks, & Complicated culture maintenance \\
\hline & & & can be passaged 7 mos, & \\
\hline & & & can be frozen & \\
\hline \multirow[t]{2}{*}{ Organotypic } & NA & Adenosine & Preserves in vivo architecture & Low throughput, more variability \\
\hline & & & & than cell cultures \\
\hline
\end{tabular}

Abbreviations: NA information not available; ON, optic nerve; oligo, oligodendrocyte; T3, thyroid hormone; no., number; mos, months. 


\section{CONCLUSIONS}

If the primary screen is performed with human cells, it is critical to have rodent oligodendrocyte in vitro assays as secondary or tertiary screens. It is essential to establish efficacy in vitro in rodent cells as these compounds will ultimately be evaluated in vivo in animal models of demyelination and remyelination. If the primary screen is performed with rodent cells or cell lines, it is equally critical, given the possibility of species specificity of drugs, to have an in vitro assessment of the positive effects of development candidate drugs in human cultures. In addition to the limitations of using in vitro rodent surrogate cells for screening drugs that will ultimately be used in patients, the choice of human cells for drug screens in vitro may influence the testing outcome. These caveats should be kept in mind with respect to expectations of compoundmediated effects in humans in clinical trials.

\section{Mechanisms: Cell Death and Myelin Damage}

Proinflammatory cytokines. Although many studies use mature rodent oligodendrocytes, their progenitors, or mixed rodent cultures to examine mechanisms of cell death, there are very few studies using human cells (Merrill and Scolding, 1999; Casaccia-Bonnefil, 2000). A review of the wide array of in vitro paradigms shows that mechanisms and pathways of cell death vary considerably. One striking example is NGF's activation of the low-affinity receptor (NGFR, in the absence of functional trkA) leading to cell death. In mature oligodendrocyte or cells where the ratio of p75 to trk is greater than $1: 1$ apoptosis occurs. Proinflammatory cytokines like IL $1 \beta, \operatorname{IFN} \gamma$, or TNF $\alpha$ can all induce ceramide production in oligodendrocytes leading to either apoptotic or necrotic cell death (Chakraborty et al, 1997; Casaccia-Bonnefil et al, 1996; Brogi et al, 1997).

Ceramide. Ceramide, a sphingolipid generated by neutral or acidic sphingomyelinase action on sphingomyelin, is a second messenger capable of mediating oligodendrocyte cell death. Apoptotic death occurs as a consequence of ceramide's elevation of c-jun through c-jun amino-terminal kinase (JNK) activity (Casaccia-Bonnefil, 2000). This agent can be used as a direct toxin in vitro to kill oligodendrocytes. Primary oligodendrocyte precursors and mature oligodendrocytes behave similarly to undifferentiated and differentiated CG4 cells, respectively, in response to C2 ceramide or C6 ceramide in that maximal cell death is achieved at $10 \mu \mathrm{M}$. Primary progenitors are more sensitive to ceramide than mature primary oligodendrocytes but CG4 cells appear to be more sensitive than primary cells in this assay. For CG4 cells, an assay time of $6 \mathrm{~h}$ is sufficient for achieving greater than $50 \%$ cell death. Primary cells generally need to be exposed to the toxin for $24 \mathrm{~h}$, especially at lower doses of C2. Astrocytes and neurons are resistant to this form of cell death. Cell-based readouts for this assay include Live/Dead cell assay (Molecular Probes, Eugene, OR), apoptosis detection kit (ApopTag Plus; ONCOR, Gaithersburg, MD), or the MTT mitochondrial enzyme function assay using 3-(4,5-dimethylthiazol-2-yl)- 2,5-diphenyl tetrazolium bromide (Boehringer, Mannheim, Germany).

Excitotoxicity. Excitotoxicity, attributable to ischemia and inflammation, has been implicated in oligodendrocyte depletion within MS lesions (Raine, 1997; Prineas, 1985; Prineas et al, 1984, 1989). Cells of the oligodendrocyte lineage express both kainate and $\alpha$-amino-3-hydroxy-5methyl-4-isoxazoleproprionate (AMPA)-type non- $N$ methyl-D-aspartic acid glutamate receptors (Patneau et al, 1994; Yoshioka et al, 1995). Prolonged activation of these receptors leads to increased intracellular calcium $\left(\mathrm{Ca}^{+}{ }^{+}\right)$, increased inositol phosphates and early gene induction and an inhibition of proliferation and migration of precursors (Gallo et al, 1996; Wang et al, 1996; Knutson et al, 1997). Mature oligodendrocyte death has also been shown to occur and can be modeled in vitro using CG4 cells that have been differentiated. Cells are cultured for $24 \mathrm{~h}$ in the presence of $2 \mathrm{mM}$ kainate and cell death is quantitated by measuring the activity of lactate dehydrogenase (LDH) (Yoshioka et al, 1995).

Free radicals. Human glial cells and macrophages are capable of making $\mathrm{NO}$ in vitro and in vivo. Increased inducible NO synthase (iNOS) responsible for pathologyinducing NO levels can be detected in MS tissue by RT-PCR (Bo et al, 1994). That the enzyme is actively producing NO is evidenced by (1) NADPH diaphorase staining in astrocytes at the edge of chronic lesions (Brosnan et al, 1994), (2) increased levels of nitrite $\left(\mathrm{NO}_{2}^{-}\right)$and nitrate $\left(\mathrm{NO}_{3}^{-}\right)$in $\mathrm{MS}$ cerebrospinal fluid (CSF) (Johnson et al, 1995), and nitrotyrosine (NT) staining in MS tissues indicative of peroxynitrite formation by the chemical reaction of NO and superoxide anion. Additional evidence that lipid peroxidation occurs in MS tissues has been put forth in other references (Prineas et al, 1984, 1989; Hunter et al, 1985; Raine and $\mathrm{Wu}, 1993)$.

Oligodendrocytes and their precursors are easily damaged by free radicals of nitrogen and oxygen, with the less mature cells being more sensitive than myelin-producing cells. Oligodendrocytes are more sensitive to the effects of free radicals than are microglia and astrocytes (Mitrovic et al, 1994; Husain and Juurlink, 1995). Cell death appears to be mainly necrotic both in MS lesions and in vitro cultures with hallmarks being process withdrawal, single-stranded DNA breaks, swollen nuclei and cytoplasm, organelle disruption, plasma membrane damage, and mitochondrial dysfunction (Prineas et al, 1984, 1989; Mitrovic et al, 1994, 1995). Thorburne and Juurlink (1996) reported that compared to astrocytes, oligodendrocytes have 23-fold more iron, lower levels of manganese superoxide dismutase, half the amount of reduced glutathione, and less than $15 \%$ the level of glutathione peroxidase. Thus, as a consequence of not being able to scavenge harmful radicals, oligodendrocytes are much more vulnerable to free radical-mediated death.

The details of in vitro assay systems to model free radicalmediated cell damage and death are described in detail elsewhere (Mitrovic et al, 1996). Mixed cultures can be set up to assess the effects of anoxia and varying degrees of hypoxia by purging closed incubation chambers with 
different ratios of $\mathrm{O}_{2}, \mathrm{~N}_{2}$, and $\mathrm{CO}_{2}$. Lipid peroxidation can be assessed using the cytochemical procedure demonstrating thiobarbituric acid fluorescent adducts in conjunction with morphological evaluation of cell death. The ability to detect cellular free radical scavenging is achieved using 5-(and -6)-carboxy-2', $7^{\prime}$-dichlorohydro-fluorescein as an intracellular probe of oxidative stress (Husain and Juurlink, 1995). A simpler and higher throughput cytotoxicity in vitro system using purified oligodendrocyte progenitors, mature oligodendrocytes, microglia, neurons, or astrocytes is that which uses chemical donors of free radicals of nitrogen and oxygen. NO is generated from $S$-nitroso- $N$-acetyl-DL-penicillamine (SNAP) whereas pyrogallol generates superoxide anion $\left(\mathrm{O}_{2}^{-}\right)$. Generation of both $\mathrm{NO}$ and $\mathrm{O}_{2}^{-}$which quickly react to generate peroxynitrite $\left(\mathrm{ONOO}^{-}\right)$can be achieved by using 3-morpholinosydnonimine- $\mathrm{HCl}$ (SIN-1); peroxynitrite can also be generated by mixing equal moles of pyrogallol and SNAP. SNAP causes significant mitochondrial enzyme damage in oligodendrocytes at $0.5 \mathrm{mM}$ but less than $25 \%$ cell death even at $2 \mathrm{mM}$. SIN-1 and pyrogallol cause significant cell death at $0.5 \mathrm{mM}$ and $100 \%$ death and mitochondrial damage at $2 \mathrm{mM}$ after $18 \mathrm{~h}$ in vitro (Mitrovic et al, 1996). Oxyhemoglobin is generally used as a positive control for inhibition of SNAP-induced mitochondrial damage (Mitrovic et al, 1994).

Quantitative multiplex assays for cell death include the release of incorporated label from proteins $\left({ }^{51} \mathrm{Cr},{ }^{3} \mathrm{H}\right.$ leucine) or nucleotides $\left({ }^{3} \mathrm{H}\right.$-thymidine), release of $\mathrm{LDH}$, or uptake of propidium iodide, trypan blue, or vital dyes. Some cell types, like astrocytes, can be damaged without dying when exposed to free radicals. Cell damage is detectable using the assay for activity of the ferrosulfur-containing enzyme succinate dehydrogenase with the Nonradioactive Proliferation/Cytotoxicity Kit or CytoTox Fluor Assay (Promega, Madison, WI). The assay is based on the ability of the intact enzyme to cleave MTT tetrazolium salt into the blue product formazan. Isocitrate dehydrogenase, a nonferrosulfur containing enzyme, is a useful control in the assay. For validation of the mechanism of cell death, techniques using EM, DNA-laddering gels, and differential alkaline precipitation of DNA to determine the proportion of DNA strands which are single-stranded as a fraction of the total cellular DNA should be employed (Mitrovic et al, 1994, 1996).

\section{CONCLUSIONS}

In lieu of using cocultures of $\mathrm{T}$ cells or macrophages/microglia and oligodendrocyte targets, the proinflammatory mediators generated by the effector cells may be added directly to mature oligodendrocytes or their precursors. High-throughput assays for viability end points are available. Determining the mechanism of cell death can be achieved by more direct and labor-intensive assays such as electron microscopy (EM) or for mixed cultures, the use of antibodies for specific cell types followed by morphological analysis (Casaccia-Bonnefil et al, 1996; Brogi et al, 1997; Larocca et al, 1997).

\section{IN VIVO MODELS}

\section{Chemically Induced Demyelination}

Cuprizone. Young adult male $\mathrm{C} 57 \mathrm{Bl} / 6$ mice at 6-8 weeks old, are susceptible to demyelination produced by a 4 to 6-week diet of $0.2 \%$ cuprizone (bis-cyclohexanone oxaldihydrazone) (Ludwin, 1978). Demyelination occurs globally throughout the white matter, but is most easily detected within the corpus callosum (Merkler et al, 2005). Demyelination is evident within 3 weeks after starting the cuprizone diet and is complete by 5 weeks. Replacement of the diet with normal food allows for almost complete remyelination within 4 weeks (Matsushima and Morell, 2001). Adamo et al (2006) have produced a similar model of demyelination in 21-day-old Wistar rats after $0.6 \%$ cuprizone for 2 weeks; remyelination occurs significantly after 2 weeks on normal diet. Immunohistochemical staining for axonal damage using amyloid precursor protein (APP) or Bielschowsky' silver impregnation did not reveal much axonal damage in 8-week-old mice (Merkler et al, 2005), though axonal transection increases significantly in 6 to 7-month-old aged mice, thereby greatly impairing repair (Irvine and Blakemore, 2006). Microglia and macrophages are required for efficient remyelination (Gilson and Blakemore, 1993) and these can be quantitated in tissue sections by staining for markers CD11b (Mac1) or biotininconjugated Ricinus communis agglutinin-1 (RCA-1; Sigma, Madison, WI). Mature oligodendrocytes numbers can be quantitated by staining with CC1 antibody (antiadenomatous polyposis coli; Calbiochem, San Diego, CA) (Adamo et al, $2006)$ or with an antibody to the $\pi$-isoform of glutathione- $S$ transferase (GST- $\pi$ ). GST- $\pi$ will not stain $\mathrm{NG} 2^{+}$immature oligodendrocytes (Mason et al, 2000, 2001). A medium throughput assay for myelin loss can be achieved by harvesting the entire brain and running quantitative MBP protein dot blots. Alternatively, a more time-consuming identification of actual tissue myelin loss and repair involves quantitative stereology using the Computer Assisted Stereological Toolbox (CAST) system (CAST GRID; Olympus, Center Valley, PA) assessment of myelin in the corpus callosum using following LFB staining. Toluidine blue and EM are necessary final steps to assure that compact myelin is investing naked axons.

When available, it is ideal to be able to apply measurements in animal models that might be used in the clinic. Merkler et al (2005) have recently demonstrated that they can produce an accurate magnetic resonance imaging (MRI) prediction of the status of myelin in the corpus callosum of cuprizone-fed mice using a combination of $\mathrm{T}_{1}$-weighted, $\mathrm{T}_{2}$-weighted, and magnetization transfer ratio (MTR) values with a $2.35 \mathrm{~T}$ Bruker (Billerica, MA) Biospin small animal MRI. Franco-Pons et al (2007) have described the use of open field and rotorod tests in the cuprizone model, claiming functional deficits in the cuprizone-fed mice compared to normal fed controls. Whether either of these translational assays will prove sensitive enough to detect drug effects in the animal model remains to be determined.

Ethidium bromide. A $0.01-0.1 \%$ solution of ethidium bromide (EtBr) can be stereotactically injected, following surgical preparation, into the thoracolumbar dorsal 
funiculus of the spinal cord or the caudal cerebellar peduncle (CCP). EtBr has also been injected into the subarachnoid space thereby causing demyelination of the optic nerves and chiasm in Sprague-Dawley or Wistar rats (8-10 weeks old). EtBr demyelination begins within $48 \mathrm{~h}$ but may not be complete before 2 weeks depending on the concentration of EtBr. As in the cuprizone model, macrophage and/or microglial cell removal of myelin debris is essential before repair (Graca and Blakemore, 1986; Guazzo, 2005). Demyelination is extensive but can be contained within a circumscribed area (such as CCP) by minimizing the volume of the injection; lesion size is also EtBr concentration-dependent. EtBr will injure all nucleated cell types because its mechanism of action is as a DNAintercolating agent. Because astrocytes are damaged within the EtBr lesion area, Schwann cells are able to migrate in and remyelinate before oligodendrocytes repopulate the area (Woodruff and Franklin, 1999; Sim et al, 2002). Spontaneous remyelination occurs from the outside of the lesion inward toward the center and is not extensive until 3.5 months following lesion production. Axons are spared but a significant proportion of naked axons remain demyelinated in the CCP 6 weeks after EtBr injection. As animals age ( $>12$ months), spontaneous remyelination in this model is less efficient (Ibanez et al, 2004; Sim et al, 2002). For the assignment of repair to exogenous stem cells during transplantation therapy, the model can be modified by local high-dose irradiation ( $40 \mathrm{~Gy} \mathrm{X}$-rays) before EtBr (Franklin and Blakemore, 1995; Blakemore and Franklin, 1991). Evaluation of oligodendrocytes, the precursors, and intact myelin can be accomplished using assays similar to those previously described above, but require tedious dissection of the lesioned area to eliminate background noise from normal surrounding areas. Honmou et al (1996) have been able to demonstrate conduction block by quantitating compound action potentials in the spinal cords of animals subjected to EtBr lesioning. Functional repair by transplanted Schwann cells reversed this slowed conduction velocity as assessed by ex vivo using field potential and intraaxonal recordings of the segment of spinal cord involved in the lesion.

\section{Lysolecithin}

Lysolecithin (lysophosphatidylcholine; Sigma) is a detergent-like membrane solubilizing agent injected following surgical preparation of brain or spinal cord and stereotaxic positioning of the Hamilton syringe. A $1 \%$ solution of the agent creates demyelinating lesions in adult mice or rats when administered to the dorsal funiculus of the spinal cord or CCP (Gregg et al, 2007; Girard et al, 2005) or into the right centrum semiovale after craniometry in adult male Macaque monkeys (Dousset et al, 1995). In mice and young adult rats, myelin debris is completely removed and remyelination has begun by 7 days after lesion in the spinal cord; total remyelination, albeit with thin myelin sheaths, was seen by 1 month (Jeffrey and Blakemore, 1995; Kotter et al, 2001). In old male rats (380 days old), the center of the lesion remained completely demyelinated at 1 month (Gilson and Blakemore, 1993). Macrophage depletion, as with the other demyelinating models, impairs remyelination (Kotter et al, 2001). For rat CCP lesions, remyelination proceeded slower than in spinal cord, with patches of oligodendrocyte progenitors obvious at lesion edges not before 2 weeks. Remyelination in the CCP was evident at 3 weeks and all axons appeared to have compact myelin by 6 weeks using EM (Woodruff and Franklin, 1999). In monkeys as in rodents, maximum myelin loss was seen by histology and magnetization transfer ratio (MTR) by day 7 (Dousset et al, 1995). Astrocytes and axons are spared in this demyelinating model, so oligodendrocytes are the primary remyelinating cell. Faster remyelination may occur because oligodendrocyte progenitors are spared to a greater extent in this model than in the EtBr model (Woodruff and Franklin, 1999). As with the EtBr model, targeted lesion areas must be dissected before analysis. See Table 2 for a comparison of the chemically induced demyelinating models.

\section{CONCLUSIONS}

There are several types of animal models that produce demyelination that can serve as useful in-life pharmacological tools for assessing compounds. Chemically induced CNS lesions, such as those generated with cuprizone feeding or injection of $\mathrm{EtBr}$ or lysolecithin have several distinct advantages: (1) dissociation of the demyelination event from the complexities introduced into the tissue pathology by chronic inflammatory cells and their soluble mediators, (2) reproducibly timed spontaneous remyelination, and (3) robust de-remyelination in anatomically distinct areas facilitating focused, quantitative assessment of lesion generation and repair (Graca and Blakemore, 1986; Jeffrey and Blakemore, 1995; Honmou et al, 1996; Woodruff and Franklin, 1999; Matsushima and Morell, 2001; Mason et al, 2000, 2004; Ibanez et al, 2004; Girard et al, 2005; Guazzo, 2005).

\section{Experimental Autoimmune Encephalomyelitis}

EAE in mice. Experimental autoimmune encephalomyelitis (EAE) is an autoimmune model produced by active immunization of rats, mice, or marmosets using whole brain or spinal cord homogenates (SCHs) or purified myelin proteins (PLP, MOG, MBP) or by adoptive transfer using activated, myelin antigen-specific $\mathrm{T}$ cells.(Genain and Hauser, 2001; Tiwari-Woodruff et al, 2007; Pluchino et al, 2003; Dalal et al, 1997; Raine et al, 1980; Wuerfel et al, 2007; Beeton et al, 2001). Analysis of inbred mouse strains has demonstrated that specific major histocompatability haplotypes (MHC) confer a susceptibility to the disease which is both gender and antigen specific. Active subcutaneous immunization of female SJL/J mice with $\mathrm{PLP}_{1-139}$ peptide emulsified in complete Freund's adjuvant (CFA) supplemented with Mycobacterium tuberculosis and two injections of pertussis toxin 3 days apart produces a relapsingremitting disease similar to MS. The disease is evident between days 7 and 10, peaking by the end of the second week in a first attack; the pathology of the first attack is 
TABLE 2 Demyelination and remyelination models in vivo

\begin{tabular}{|c|c|c|c|c|c|c|c|c|c|c|c|}
\hline Model & Species & $\begin{array}{c}\text { Demyelinating } \\
\text { agent }\end{array}$ & $\begin{array}{c}\text { Time to } \\
\text { demyelination }\end{array}$ & $\begin{array}{l}\text { Lesion } \\
\text { location }\end{array}$ & $\begin{array}{l}\text { Axonal } \\
\text { loss }\end{array}$ & $\begin{array}{l}\text { Spontaneous } \\
\text { remyelination time }\end{array}$ & $\begin{array}{c}\text { Remyelinating } \\
\text { agents }\end{array}$ & $\begin{array}{l}\text { Functional } \\
\text { readout }\end{array}$ & $\begin{array}{l}\text { Technical } \\
\text { complexity }\end{array}$ & $\begin{array}{l}\text { Model } \\
\text { pros }\end{array}$ & $\begin{array}{l}\text { Model } \\
\text { cons }\end{array}$ \\
\hline \multirow[t]{2}{*}{ Lysolecithin } & Rat, mouse & $1 \%$ lysophospha- & $48 \mathrm{hrs}$ & СCP & Minimal & 1 week start & Prolactin & None & Stereotactic & Localized lesion & Long time in-life, \\
\hline & & tidylcholine & & dorsal funiculus SC & & 4-6 weeks complete & & & injection & Short time in-life & tech. complex \\
\hline Ethidium & Wistar or SD rat & $0.01-0.1 \% \mathrm{EtBr}$ & 48 hrs start & CCP & Minimal & 6-8 weeks start & Progesterone & None & Stereotactic & Localized lesion & Long time in-life, \\
\hline bromide (EtBr) & & & 2 weeks complete & & & 3-4 months complete & schwann cells & & injection & & tech. complex. \\
\hline \multirow[t]{3}{*}{ Cuprizone } & Wistar rat & $0.6 \%$ cuprizone & 2 weeks start & $\begin{array}{l}\text { Global white } \\
\text { matter }\end{array}$ & Minimal & 2 weeks significant & $\begin{array}{l}\text { Spontaneous } \\
\text { Apotransferrin }\end{array}$ & & Low & $\begin{array}{l}\text { Precise timing of } \\
\text { de-remyelination, }\end{array}$ & Long time in-life \\
\hline & C57B//6 mouse & $0.2 \%$ cuprizone & 3 weeks start & Global white & Minimal & 4 weeks significant & Spontaneous & Open field & Low & non-inflammatory, & Functional readouts \\
\hline & & & 5 weeks complete & matter & & & IGF-1, IL1ß & rotorod & & specific to oligo & not yet validated \\
\hline \multirow[t]{4}{*}{ EAE } & DA rat & $\mathrm{rSCH}, \mathrm{MOG}$ & 3 weeks start & Cervical SC & Significant & Unknown & Thyroid hormone & Neurological score & Low & Relasping-remitting & Long time in-life \\
\hline & & & & & & & & VEP, SSEP & & pathology like MS & \\
\hline & SJL/J mouse & $\mathrm{PLP}_{1-139}$ & 3 weeks start & Lumbar SC & Significant & Unknown & $\begin{array}{l}\text { LIF, } 17-\beta \text {-estradiol } \\
\text { Testosterone }\end{array}$ & Neurological score & Low & $\begin{array}{l}\text { Relasping-remitting } \\
\text { pathology like MS }\end{array}$ & Long time in-life \\
\hline & C57Bl/6 mouse & $\mathrm{MOG}_{\mathrm{r} 335-55, \mathrm{h1}-125}$ & 10-14 days & Lumbar SC & Significant & Unknown & $\begin{array}{l}\text { LIF, 17- } \beta \text {-estradiol } \\
\text { IGF-1, anti-LINGO }\end{array}$ & Neurological score & Low & $\mathrm{Tg} / \mathrm{KO}$ compatible & \\
\hline \multirow[t]{7}{*}{ Antibody+C' } & Rat & Anti-GalC+C' & 3 days start & Lumbar SC & None & 2 weeks start & & & Stereotactic & Short time to & Long time in-life, \\
\hline & & & & & & 2 months complete & & & injection & demyelinate & tech. complex \\
\hline & & Anti-GalC+C' & 5 days start & ON & None & 3-4 weeks start & PDGF & & Stereotactic & Short time to & \\
\hline & & & 2 weeks complete & & & & & & injection & demyelinate & Tech. complex \\
\hline & & Anti-GalC+C' & 2 weeks start & CCP & None & $\begin{array}{l}6 \text { weeks start } \\
3-4 \text { months complete }\end{array}$ & & & $\begin{array}{l}\text { Stereotactic } \\
\text { injection }\end{array}$ & Localized lesion & $\begin{array}{l}\text { Long time in-life, } \\
\text { tech. complex }\end{array}$ \\
\hline & Guinea pig & Anti-GalC+C' & 5 days start & ON & None & 3-4 weeks start & & & Stereotactic & Short time to & \\
\hline & & & 2 weeks complete & & & & & & injection & demyelinate & Tech. complex \\
\hline
\end{tabular}

Abbreviations: C', complement; SD, Sprague-Dawley; DA, Dark Agouti; rSCH, rat spinal cord homogenate; MOG, myelin oligodendrocyte glycoprotein; MRI, magnetic resonance imaging; PLP, proteolipid protein; Gal C, galactocerebroside; CCP, caudal cerebellar peduncle; SC, spinal cord; VEP, visual evoked potential; SSEP, somatosensory evoked potential; oligo, oligodendrocyte; MS, multiple sclerosis; Tg, transgenic; KO, knockout; tech., technical. 


\begin{tabular}{|c|c|c|c|}
\hline Haplotype & Strain & Antigen & Disease type \\
\hline$H-2^{q}$ & DBA-1 & $\mathrm{rMOG}_{1-125}$ & Chronic \\
\hline \multirow[t]{2}{*}{$\mathrm{H}-2^{\mathrm{s}}$} & SJL/J & $\mathrm{PLP}_{1-139}$ & Relapsing-remitting \\
\hline & & MBP & Relapsing-remitting \\
\hline $\mathrm{H}-2^{\mathrm{dq} 1}$ & ABH Biozzi & PLP & Chronic \\
\hline \multirow[t]{4}{*}{$\mathrm{H}-2^{\mathrm{b}}$} & C57BI/6 & $\mathrm{rMOG}_{1-125}$ & Chronic, T dep demyelination \\
\hline & & $\mathrm{hMOG}_{1-125}$ & Chronic, Ab dep demyelination \\
\hline & & $\mathrm{rMOG}_{35-55}$ & Chronic, T dep demyelination \\
\hline & & $\mathrm{hMOG}_{35-55}$ & Very little disease, no demyelination \\
\hline $\mathrm{H}-2^{\mathrm{u}}$ & $\mathrm{PL} / \mathrm{J}$ & $\mathrm{MBP}_{1-9 \mathrm{NAc}}$ & Chronic \\
\hline $\mathrm{H}-2^{\mathrm{u}}$ & B10PL & $\mathrm{MBP}_{1-9 \mathrm{NAC}}$ & Chronic \\
\hline \multirow[t]{2}{*}{$\mathrm{H}-2^{\mathrm{g}}$} & $\mathrm{NOD} / \mathrm{Lt}$ & PLP & Chronic \\
\hline & & $\mathrm{rMOG}_{1-125}$ & Chronic \\
\hline
\end{tabular}

(Bernard, 1976 ; Arnon, 1981; Offner, 2004)

strictly inflammatory. Following a remission, the subsequent attacks include inflammation, demyelination and axonal loss. $T$ cells, dendritic cells, macrophages, and endogenous glia all are involved in the disease (Butzkueven et al, 2002). In contrast, $\mathrm{rMOG}_{35-55}$ or $\mathrm{hMOG}_{1-125}$ induce chronic $\mathrm{EAE}$ in female $\mathrm{C} 57 \mathrm{Bl} / 6$ mice. Inflammation, demyelination, oligodendrocyte and neuronal death, and axonal loss occur within the first 2 weeks of disease. Human $\mathrm{MOG}_{1-125}$ induces demyelination that is primarily antibody mediated and thus produces a pathology similar to that seen in MS lesions (Table 3; Tiwari-Woodruff et al, 2007; Kanwar et al, 2004; Lalive et al, 2006; Bernard, 1976; Arnon, 1981; Offner, 2004).

These two models are complementary in their utility for drug discovery. Because of the temporal separation of pathologies (inflammation $v s$ tissue damage) and the relapsing-remitting nature of the disease, the PLP model allows for the assessment of both anti-inflammatory and prorepair drugs as well as a comparison of prophylactic with therapeutic intervention. The chronic C57Bl/6-MOG models (1) allow for the specific assessment of agents targeting $\mathrm{B}$ cells $\left(\mathrm{hMOG}_{1-125}\right.$ model), (2) demonstrate axonal damage and cell death at an earlier time point than is seen in the PLP model, thereby shortening the in-life dosing, and (3) are compatible with creation of knock out and transgenic mice for target and drug validation.

$E A E$ in rats. Even though rat models consume more drug substance than do mouse models, the rat EAE models may be necessary for proof of concept assessment due to the selectivity and/or pharmacokinetics or pharmacodynamics of the drug being tested. In addition, assessment of drug effects using MRI or electrophysiology may be made more easily using rats (Bechtold et al, 2004; Brochet et al, 2006). Acute, nonrelapsing EAE can be actively induced in Lewis rats using guinea pig SCH or MBP, CFA, and M. tuberculosis (Floris et al, 2004; Berger et al, 2006). By increasing the concentration of the encephalitogenic antigens and/or $M$. tuberculosis, the disease phase can be prolonged and induction of a relapsing pattern achieved in this strain of rat (Feurer et al, 1985). The acute monophasic model in Lewis rats demonstrates neurological deficits by day 10 , peaks at day 15 , and resolves by day 20 , at which time animals are resistant to reinduction of disease. This model is one of relatively short duration which is an advantage, but as there is no demyelination, cell death, or axonal loss, its use is limited to the assessment of antiinflammatory drugs only. Rat $\mathrm{MOG}_{1-125}$ will induce chronic, nonrelapsing EAE in female Brown Norway rats when given with CFA and $M$. tuberculosis (Mi et al, 2007; Diem et al, 2005). When the same dose of MOG is given to female Dark Agouti (DA) rats or whole homologous rat $\mathrm{SCH}$ is given to male DA rats without $M$. tuberculosis, animals develop relapsing-remitting disease (Issazadeh et al, 1996; Lorentzen et al, 1995; Brochet et al, 2006; Fernandez et al, 2004; Figure 1). As in the relapsing-remitting model in SJL/J mice, peak disease in DA rats is achieved by the end of the second week followed by remission and is strictly inflammatory in nature; animals experience disease through the first remission in a relatively synchronous manner. Subsequent attacks are asynchronous among animals and involve demyelination involving macrophages and anti-myelin antibodies as well as axonal loss (Lorentzen et al, 1995; Issazadeh et al, 1996).

Inflammation can be verified in these models by RT-PCR and staining for proinflammatory markers of cells and their products. In rat EAE models, it has recently been shown that macrophages can be tracked in vivo by $\mathrm{T}_{2}$-weighted MRI images of these cells labeled with ultra small particles of iron oxide (USPIO) (Sinarem; Guerbet, Paris, France). The particles are phagocytosed by macrophages in the periphery and in the DA rat EAE model as these cells migrate first into the cervical cord and subsequently into the brain stem and cerebellum with disease progression, they can be detected as hypointense images. With a half-life of only a few hours, USPIOs can be injected repeatedly into animals. Longitudinal studies mapping time and location of inflammatory cells in intact animals can thereby be accomplished. In addition, contrast agents such as gadolinium diethylenetriamine-pentaacetate (Gd-DPTA) (Magnevist; Schering, Berlin, Germany) and gadofluorine $\mathrm{M}$ (Schering) have been used in $\mathrm{T}_{1 \text {-weighted MRI images for }}$ discerning leakage at the BBB. Correlations can then be made regarding $\mathrm{BBB}$ breakdown and inflammatory cell invasion of the CNS (Brochet et al, 2006; Berger et al, 2006). Similar studies have been reported in murine adoptive transfer models of EAE (Wuerfel et al, 2007; Smorodchenko et al, 2007; Anderson et al, 2004). MBP exon 2-containing transcripts, normally expressed at extremely low levels in adult CNS, are elevated during remyelination and can be detected in tissues using in situ hybridization (ISH) or immunohistochemistry (Jordan et al, 1990; Kanwar et al, 2004). In these models, myelin and axonal damage or loss are identified as described above for chemically induced lesions using myelin histology, toluidine blue, LFB, immunostaining for NF or APP, and EM.

As in the lysolecithin-mediated demyelination model, MRI magnetization transfer ratios (MTRs) can be used as a measurement of myelin loss in EAE models. Diffusion tensor imaging (DTI) takes advantage of the anisotropic nature of water diffusion in tissue to allow for detailed 
Induction of EAE in dark agouti (DA) rats

disease produced is gender and antigen dependent
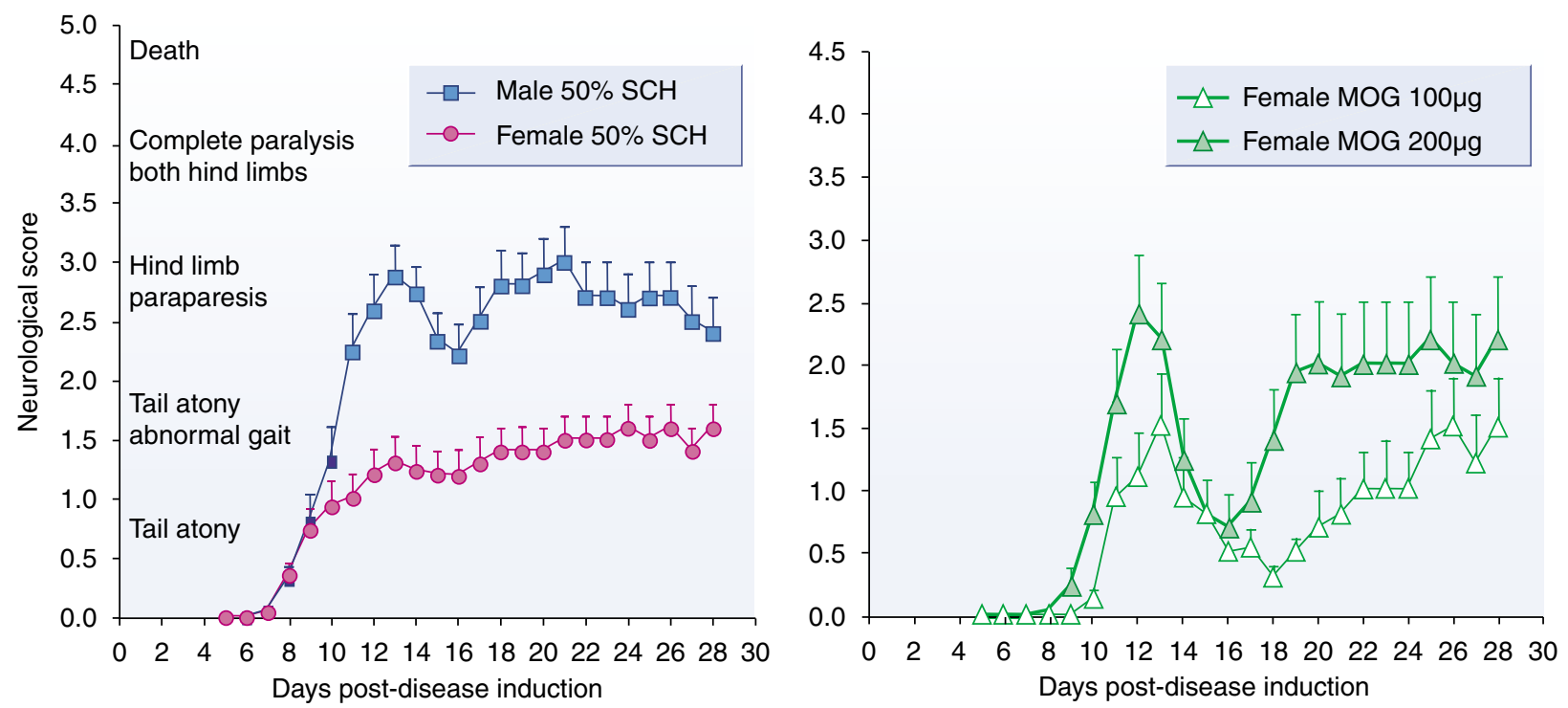

Figure 1. Induction of experimental autoimmune encephalomyelitis (EAE) in Dark Agouti (DA) rats. Disease produced is gender and antigen dependent. EAE disease in male or female adult DA rats was induced with either whole rat spinal cord homogenate (SCH) emulsion $50 \%$ w/v in saline or myelin oligodendrocyte glycoprotein (MOG) antigen (100 or $200 \mu \mathrm{g}$ ) and complete Freund's adjuvant (CFA) containing $7 \mathrm{mg} / \mathrm{ml}$ at day 0 . Neurological scores were assessed daily post-disease induction.

microstructural information and is used to confirm axonal integrity. Both MTR and DTI techniques have been used in rats and marmoset EAE models (Mi et al, 2007; Berger et al, 2006; Fujiyoshi et al, 2007; Brok et al, 2001). Thus, small animal MRIs (1.5 T magnet, Philips, Best, The Netherlands $7 \mathrm{~T}$ Bruker; $4.7 \mathrm{~T}$ horizontal bore NMR spectrometer, Varian, Palo Alto, CA) are becoming more readily available and standardly used for chronic in-life monitoring of pathology in EAE models.

Other demyelinating models. There are several models of spinal cord injury and focal ischemia that lead to demyelination with partial sparing of axons that can be produced in rodents and monkeys. Spinal cord lesions can be created weight drop contusion and hemisection and ischemic insult can be produced by a $90 \mathrm{~min}$ middle cerebral occlusion (MCAO). Although these models cannot be fully explored in this chapter, they are mentioned because they induce endogenous repair responses that lend themselves to the same quantitative biochemical, histological, and MRI analyses, drug intervention, and stem cell therapy as seen in EAE models (Tanaka et al, 2003; Ohori et al, 2006; Fujiyoshi et al, 2007; Yang et al, 2006).

The location of injection, the length of time for infusion, and the properties of the toxic agent will define whether damage is limited and reversible, is restricted to oligodendrocytes but without long-term macroscopic alterations, leads to short-term direct attack on myelin, or results in long-term damage to myelin indirectly due to oligodendrocyte loss. The injection of the peroxynitrite donor SIN-1 into white matter corpus callosum in rats leads to severe myelin alteration within 2 days starting with vacuolization of the myelin membrane as a consequence of $S$-nitrosylation of proteins including PLP (Boullerne and Benjamins, 2006).

A brief infusion of kainate causes some oligodendrocyte apoptosis but an infusion that lasts for several days produces massive oligodendrocyte and progenitor cell death, demyelinating plaques, axonal damage, and inflammation (Matute et al, 2001). A single dose of 8 or $22 \mathrm{~Gy}$ irradiation to rodent $\mathrm{C} 2-\mathrm{T} 2$ cervical spinal cord produces apoptotic oligodendrocytes after $24 \mathrm{~h}$ but no demyelination until 16-18 weeks later (Atkinson et al, 2003). Injections of kainate or anti-galactocerebroside (anti-Gal C) may be made into the optic nerve, dorsal spinal cord or CCP, thereby focusing the lesion formation and facilitating subsequent analysis of damage and repair (Sergott et al, 1985; Woodruff and Franklin, 1999; Barres et al, 1992).

Although most published studies employing anti-Gal C used a conventional polyclonal antibody or serum from rabbits in combination with guinea pig complement, Barres et al (1992) implanted a mouse hybridoma cell line secreting anti-Gal $\mathrm{C}$ into the $\mathrm{p} 5$ rat optic nerve. Injection of antibody and complement into the adult rat lumbar cord showed demyelination by day 3 , remyelination commencing by day 14 , and complete remyelination by day 60 (Keirstead et al, 1998) Sergott et al (1985) injected antibody and complement into the guinea pig optic nerve and demonstrated myelin vesiculation by day 5 , naked axons between days 7 and 14, and remyelination beginning between days 21 and 35. Injection of antibody and complement into the CCP produced the greatest delay in demyelination and repair: demyelination was seen at 2 weeks and remyelination by oligodendrocytes started by 6 weeks after injection. 
Administration of teriflunomide in Lewis rat acute EAE model

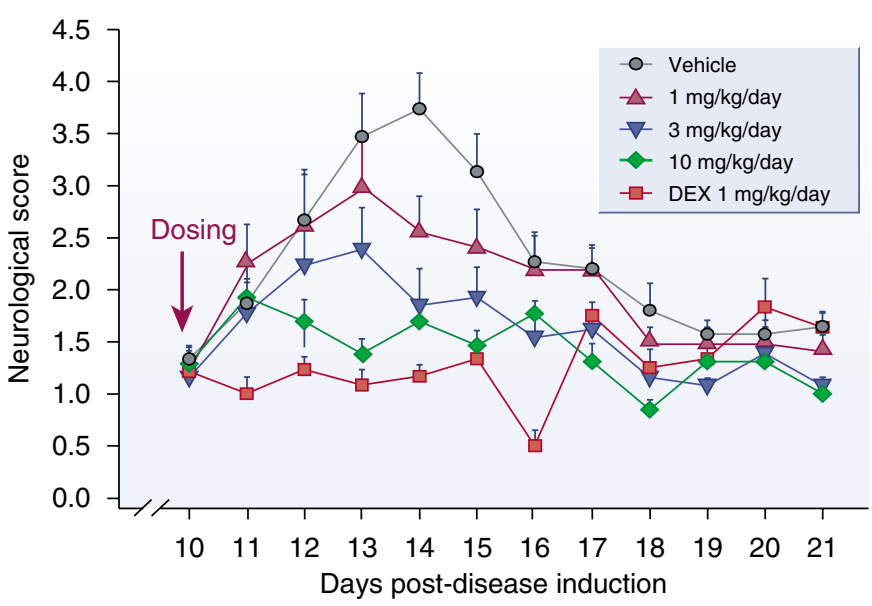

Prophylactic administration of teriflunomide in $\mathrm{PLP}_{1-139} \mathrm{SJL} / \mathrm{J}$ relapsing-remitting EAE model

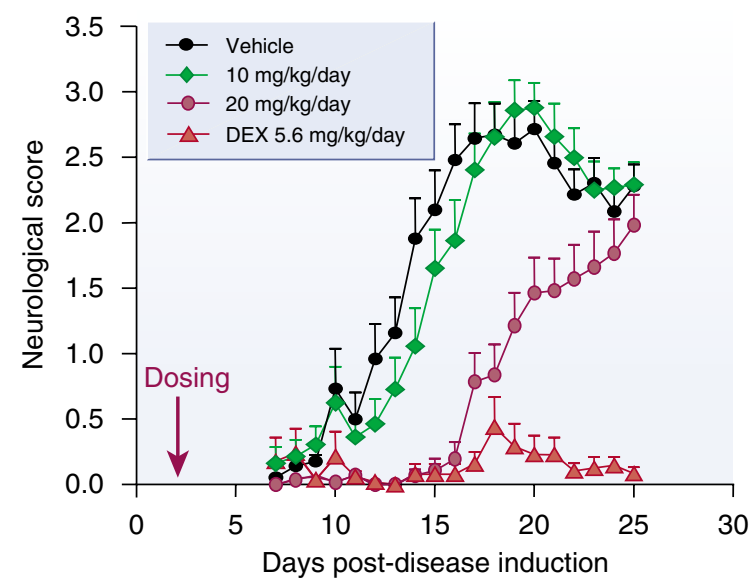

Therapeutic administration of teriflunomide in DA rat relapsing-remitting EAE model (dosing at onset of disease)

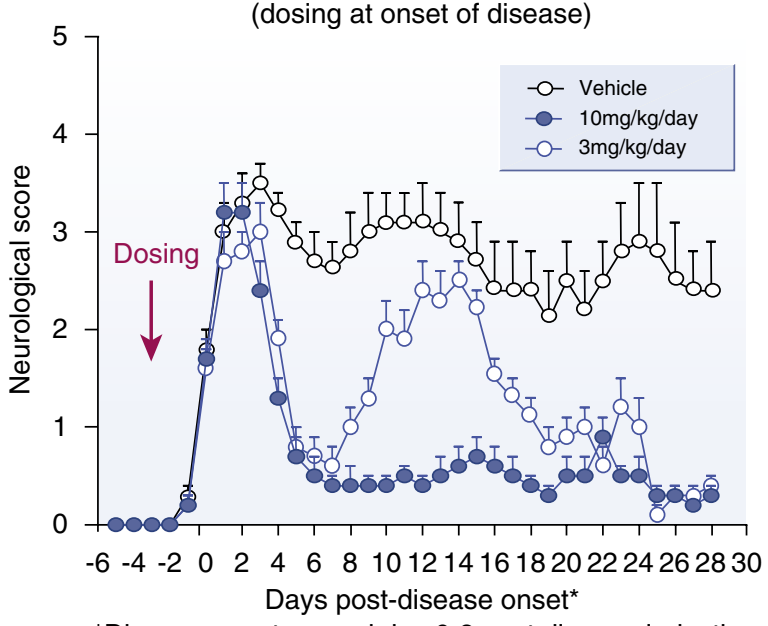

*Disease onset around day 6-8 post disease induction

Prophylactic administration of teriflunomide in MOGh ${ }_{1-125} \mathrm{C} 57 \mathrm{BI} / 6$ Chronic EAE model

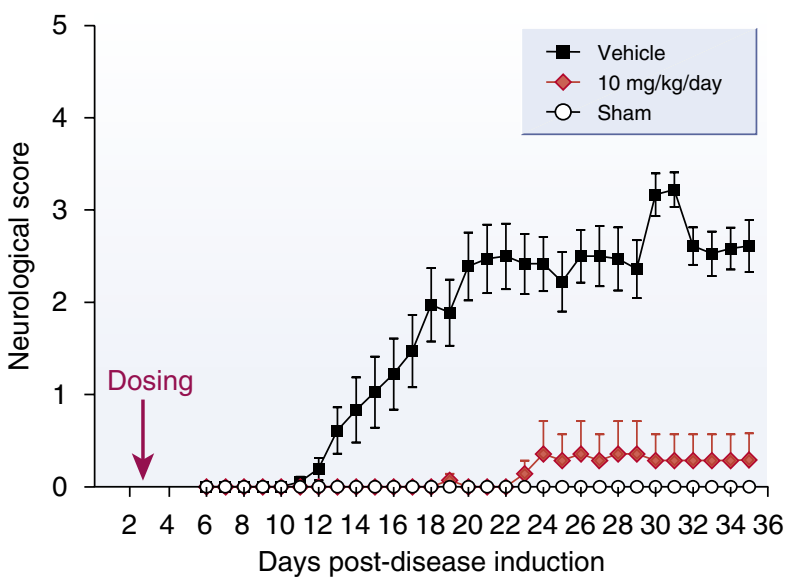

Figure 2. A comparison of the effects of administration of teriflunomide in experimental autoimmune encephalomyelitis (EAE) models in rats and mice. EAE was induced in rats and mice to produce acute, chronic, or relapsing-remitting disease. Vehicle controls were not treated with teriflunomide. EAE in Dark Agouti (DA) rats was induced with $50 \%$ spinal cord homogenate (SCH) w/v in saline (Figure 1). Sham-injected animals did not receive encephalitogen but did receive diluent, complete Freund's adjuvant (CFA), M. tuberculosis, and/or pertussis toxin according to the model. DEX is dexamethasone. The doses of teriflunomide and the day of first dosing post-disease induction are indicated by red arrows.

Extensive remyelination within the CCP was apparent at 8 weeks but it took 3.5 months for the repair to be complete (Woodruff and Franklin, 1999). A comparison of these demyelinating models is summarized in Table 2.

\section{CONCLUSIONS}

Bypassing induction of global inflammation as an alternative strategy for in vivo demyelination can be achieved by administering agents that directly damage oligodendrocytes, their precursors, or myelin. Anti-GalC plus complement, kainite, SIN-1, irradiation, and Theiler's or corona virus infection are examples of such models (Dal Canto and Lipton, 1976; Jordan et al, 1990; Touil et al, 2001; Matute et al, 2001; Atkinson et al, 2003; Boullerne and Benjamins,
2006). In general, the use of mouse models is preferred because less drug substance is required; this of considerable importance when daily dosing paradigms are chronic, lasting several weeks. However, in the case of (1) particular requirements of model generation or analysis that lend themselves to one species over another, (2) the lack of identical molecular targets or adequate homology at the target molecule in some species of rodents compared to humans, (3) species-specific potency of certain drugs, and (4) pharmacokinetic properties peculiar to a given species, the use of rats, guinea pigs, and nonhuman primates may be necessary for in vivo drug screening.

EAE models are of interest in drug screening as they most faithfully represent the pathology seen in MS The use of the marmoset EAE model can take advantage of the potential 
Therapeutic administration of teriflunomide in DA rat EAE model (dosing at remission)

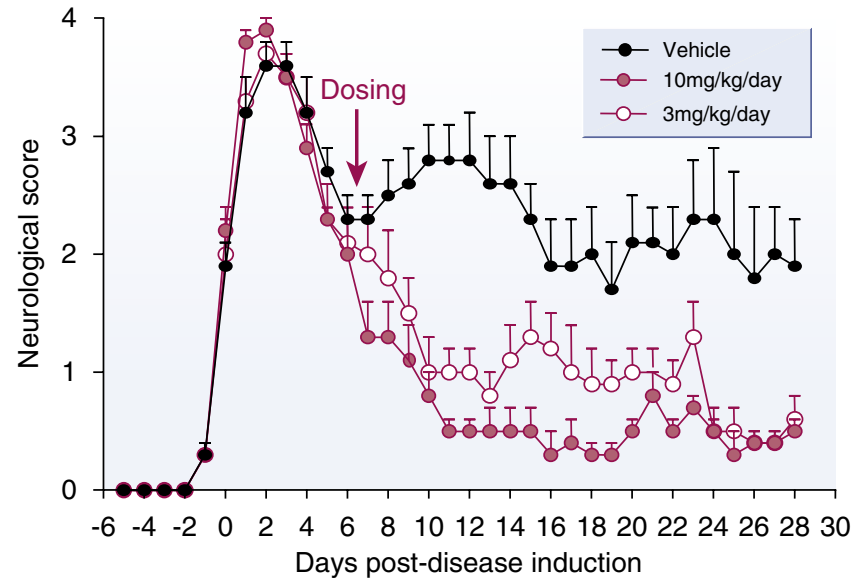

Therapeutic administration of teriflunomide in $\mathrm{PLP}_{1-139} \mathrm{SJL} / \mathrm{J}$ relapsing-remitting EAE model (dosing from day 7 to day 25)

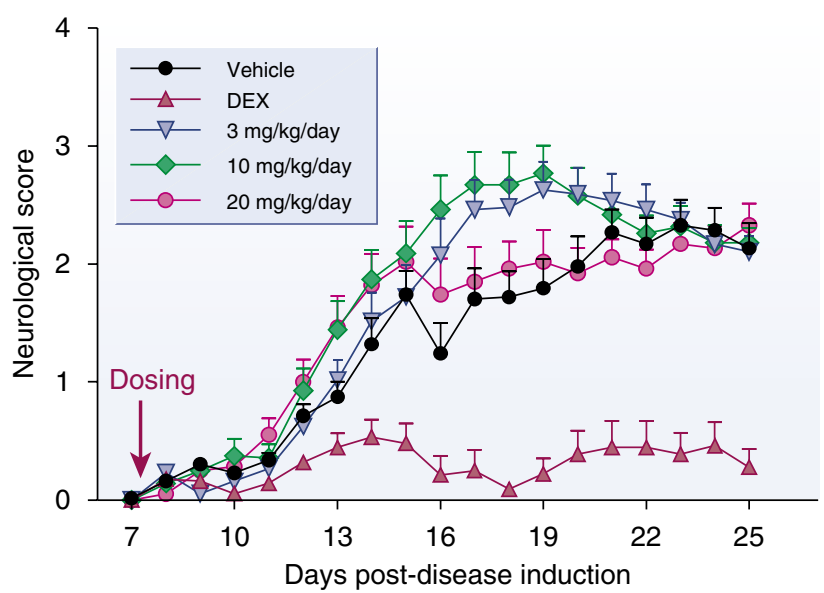

Figure 3. Therapeutic administration of teriflunomide in relapsing-remitting experimental autoimmune encephalomyelitis (EAE) models in rats and mice. EAE was induced in rats and mice to produce relapsing-remitting disease. Vehicle controls were not treated with teriflunomide. EAE in Dark Agouti (DA) rats was induced with $50 \%$ spinal cord homogenate $(\mathrm{SCH}) \mathrm{w} / \mathrm{v}$ in saline (Figure 1). DEX is dexamethasone and was dosed at $5.6 \mathrm{mg} / \mathrm{kg}$ per day. The doses of teriflunomide and the day of first dosing post-disease induction are indicated by red arrows.

for cross-reactivity in the monkey of therapeutic agents as well as human reagents for cell and biomarker identification. In addition, MRI and electrophysiological techniques may be employed in the model. Cognitive and visual acuity assessments and chronic safety can also be conducted in this model providing an advantage over rodent models.

\section{IN VIVO PHARMACOLOGICAL TOOLS}

Remyelination can be achieved in vivo in demyelinating animal models using several different approaches. The use of antiinflammatory drugs may create a permissive environment for endogenous repair to occur in the absence of ongoing disease (Floris et al, 2004; Dalal et al, 1997; Kanwar et al, 2004; Tiwari-Woodruff et al, 2007). There are many published studies demonstrating the efficacy of growth factors or small molecules that induce expansion of precursors, recruit them to sites of pathology, and drive differentiation of endogenous oligodendrocyte progenitors (Okano et al, 2007; Stangel, 2004; Franklin, 2002; Webster, 1997; Oudega et al, 1997; Lachapelle et al, 2002; Adamo et al, 2006). Neuroprotective drugs and hormones that preserve the integrity and function of cells, axons, and myelin in spite of ongoing pathology have been successfully used in animal models to permit repair (Diem et al, 2004; Stangel, 2004; Butzkueven et al, 2002; Mason et al, 2000; Tiwari-Woodruff et al, 2007, Kanwar et al, 2004). Antibody neutralization of inhibitory molecules which block remyelination is also effective in vivo ( $\mathrm{Mi}$ et al, 2007). Stem cells, which will not be reviewed in any depth in this chapter, can either replace precursors that have been depleted by chronic demyelination and/or produce factors that reduce glial scarring, inflammation, and axonal loss (Mason et al, 2004; Pluchino et al, 2003).

\section{Small Molecules}

Small molecules that have been chemically engineered to be potent, selective, soluble, and orally available may be preferable to biologics in that they can be taken by the patient him/herself as a pill and they may have fewer side effects such as irritation at injection site or flu-like symptoms. One such molecule is teriflunomide, an inhibitor of dihydroorotate dehydrogenase, currently in Phase III trials for the treatment of MS. It is an antiinflammatory agent that inhibits $\mathrm{T}$ - and $\mathrm{B}$-cell proliferation and function. This drug is a contender to be among the first orally available drugs to treat the disease (O'Connor et al, 2006). Teriflunomide is very active in several EAE models when administered by oral route once daily. In DA rats it reduces induction and severity of EAE, inhibits demyelination, prevents axonal loss, and increases conduction velocity (manuscript accepted, J Neurol). The in vivo effects of teriflunomide provide an example of the species and straindependent differences that are seen in different EAE models with respect to minimal effective dose and efficacy (Figures 2 and 3). In both the acute Lewis rat and relapsingremitting DA rat EAE models, the drug is efficacious at a minimal effective dose of $3 \mathrm{mg} / \mathrm{kg}$; at this dose the disease is virtually eliminated in the acute model whereas delayed and reduced in severity in the relapsing-remitting model (Figure 2). In the PLP-induced SJL/J EAE mouse model, a prophylactic dose of $10 \mathrm{mg} / \mathrm{kg}$ has no effect at all whereas $20 \mathrm{mg} / \mathrm{kg}$ delays onset of disease. Although delayed, these mice eventually get EAE disease as severe as the vehicle controls. However, $10 \mathrm{mg} / \mathrm{kg}$ teriflunomide given prophylactically to MOG-induced $\mathrm{C} 57 \mathrm{Bl} / 6$ mice eliminates disease induction (Figure 2). Teriflunomide is more effective at $3 \mathrm{mg} / \mathrm{kg}$ given therapeutically during remission in the DA rat model than when given prophylactically in this model. 
But the drug is totally ineffective when given therapeutically at disease onset in the SJL/J mouse model (Figure 3).

An explanation as to the difference between drug effects in the relapsing-remitting models in SJL/J mouse and DA rat may be that teriflunomide is 6 -fold less potent in enzyme binding and inhibition in the mouse than in the rat and 100fold lower in its antiproliferative activity on mouse lymphocytes than rat lymphocytes (Fox et al, 1999). Clearly, there is a different explanation for the difference between the drug's effects in the two different mouse EAE models. Because the time course of pathology in these two mouse EAE models differs so significantly (see above), it might be anticipated that the drug may affect additional cell types than T and B cells involved in the MOG model. This aspect of the therapeutic efficacy is currently being investigated.

\section{Antibodies}

Antibodies as biological agents will not cross an intact BBB and they cannot be delivered orally, but need to be injected. In animal models, antibodies are generally injected intraperitoneally (i.p.) or intravenously (i.v.) by tail vein injection. Antiinflammatory antibodies act on cells in the peripheral blood to prevent their accessing of or functioning in the CNS and can be administered less frequently (ie not once a day chronically) than small molecules and still be effective. Kanwar et al (2004) describe the antiinflammatory antibody to mucosal addressin cell adhesion molecule-1 (MAdCAM-1) whose effects, after only three injections of $10 \mathrm{mg} / \mathrm{kg} \mathrm{IV}$, were sustained for several months as a monotherapy. The effects of this antiinflammatory antibody in conjunction with an IGF-1 peptide for repair and an AMPA/kainate receptor antagonist 2,3-dihydroxy-6-nitro-7sulfamoylbenzo-(f)-quinoxaline (NBQX) for neuroprotection were even better than antibody alone. This study represents an example of combination therapy of complimentary drugs treating different aspects of the disease that might be envisioned for the treatment of MS.

However, if the cellular or molecular target for the antibody treatment resides within the CNS, and the BBB is intact, then a strategy for delivery of the antibody to the site of the pathology is required. Anti-LINGO-1 antibody was delivered intrathecally by way of an Alzet mini-osmotic pump into animals with MOG-induced EAE where it inhibited a key negative regulator of oligodendrocyte differentiation and myelination. Within 2-3 weeks of treatment, EAE disease was slowed, axonal integrity preserved, and spinal cord remyelination initiated (Mi et al, 2007).

\section{Neurotrophic Factors and Hormones}

Neurotrophic factor proteins are difficult to deliver chronically as exogenous therapeutic agents in animal models because they need to be injected frequently or released in a sustained fashion, they may have a short plasma half-life, and they may induce neutralizing anti- bodies rendering them ineffective with time. Some investigators have applied innovative strategies to demonstrate the positive role of neurotrophic factors in oligodendrocyte cell survival in demyelinating models. Mason et al (2000) solved the problem of chronic IGF-1 delivery by creating the cuprizone model in IGF- $1+1+$ transgenic mice, whereas Barres et al, (1992) delivered PDGF on the CNS side of the BBB by implanting a hybridoma cell line secreting the neurotrophic factor. Oudega et al (1997) used semipermeable polymer tubes containing Matrigel implants of Schwann cells bathed in IGF-1 and PDGF. Alzet mini pumps can be implanted SC or IP as in the case of prolactin delivery to drive remyelination (Gregg et al, 2007). Subcutaneous sustained release pellets have been used for delivery of estrogen for oligodendrocyte protection, progesterone for producing myelin repair within 3-5 weeks, and testosterone, whose therapeutic administration eliminated MBP-induced EAE in SJL/J mice (Offner, 2004; Ibanez et al, 2004; Dalal et al, 1997).

A simpler mode of drug delivery that avoids the need for genetic manipulation of cells or animals, the use of devices, or complexities of surgical implantation but accommodates sustained drug exposure and BBB penetration is daily subcutaneous injection. This has been successfully used for administration of the neurotrophic factor LIF and hormones like thyroid hormone (T4) and estrogen (E2) in EAE (Butzkueven et al, 2002; Tiwari-Woodruff et al, 2007; Fernandez et al, 2004). It has been documented that LIF can enter the CNS and mediate survival of oligodendrocytes; it is equally effective given IP but ineffective when administered IV (Butzkueven et al, 2002). Estrogen is both antiinflammatory and neuroprotective in ovariectomized mice with EAE. If given prophylactically, estrogen's neuroprotective effect is not evident until after day 20 in the MOG EAE model. However, delaying treatment until that time shows that estrogen has no effect. Indeed the hormone works better in murine EAE models if started 7 days before disease induction (Offner, 2004; TiwariWoodruff et al, 2007). As has been mentioned for small molecules above, there are significant mouse strain differences with respect to sensitivity to the neuroprotective effects of estrogen that should influence the choice of the model and the impact of the results (Offner, 2004). A summary and comparison of some of these features of the in vivo models is shown in Table 2.

\section{CONCLUSIONS}

In vivo repair can be greatly influenced by the animal models chosen as proof of concept models. Additional complexity is added by the fact that neurotrophic factors like IGF-1 and GGF are not only neuroprotective agents and promote remyelination but can also act as antiinflammatory molecules. Lymphocytes may produce neurotrophic factors (T-cell production of BDNF) and proinflammatory cytokines (IFN $\gamma, \mathrm{TNF} \alpha)$ may act as pro-repair molecules 
(reviewed by Stangel, 2004). The route/location and timing of drug delivery that is chosen to be used in various models may be dictated by the physical characteristics of the drug and targeted pathology to be affected. The ease or difficulty of drug delivery to the site of action in models depends on the nature of the therapy (small molecule $v s$ biological agent vs transplanted cells), pharmacokinetics of exposure (metabolism, clearance, drug on-off rate kinetics), bloodbrain penetrability, and solubility, among other characteristics.

\section{COMPOUND SCREENING TREE: AN EXAMPLE}

To illustrate the flow of a screening tree for a library of small molecular weight compounds starting with the primary screen through to the proof of concept (POC) models, we can consider a receptor whose activation is necessary for oligodendrocyte differentiation and ultimately remyelination as a hypothetical target. The primary screen could be a promoter-reporter based screen for a gene directly and specifically activated by ligand binding to the receptor. Such a screen could be performed in a 1536-well plate format using a half million compounds at a single dose and would require $10^{9}$ cells. Following validation of an assay system with standard tools as positive controls, such a primary screen could be conducted using a stably transfected rodent oligodendrocyte cell line such as CG4. If the hit rate is $0.5 \%$ ( 2500 compounds), reconfirmation and $\mathrm{IC}_{50} \mathrm{~s}$ would be performed with 10 million CG4 cells. The orthogonal secondary screen, usually performed on hundreds of active compounds, could be carried out with CG4 cells or primary oligodendrocytes and might be a receptor binding assay; this assay would also require millions of cells. The tertiary screen, involving differentiation of primary rodent oligodendrocyte precursors, would likely involve tens to hundreds of compounds and could be performed in a 96-well format requiring 5-10 million cells. The human orthologue assay to screen fewer than 50 compounds should be performed using primary human fetal or adult-derived progenitors. An additional screen for induction of myelination using a mixed cell culture is optional at this stage. With fewer than 10 compounds to be pursued, an acute in vivo model for assessment of the ability of the molecule to enter the brain and hit its molecular target would be performed next. Such a model would have a fast turnaround of hours to 1-2 days and could have biochemical or molecular readouts. The assessment of remyelination would then be performed in a remyelination model such as the cuprizone model; this would be reserved for 1-2 lead compounds. With the development candidate chosen, the final assessment of the compound's ability to drive remyelination would be performed in a disease POC model such as in EAE, the model of choice for development of drugs to treat MS.

\section{FUTURE RESEARCH DIRECTIONS}

The future holds promise for the use of drugs which drive repair of the CNS. As the MRI technologies such as MTR and DTI for distinguishing and quantitating repair of the nervous system in humans become refined and standardized, they will be incorporated into the growing use of small animal MRI for assessing drugs that drive remyelination in animal models and used more routinely in human clinical trials. Peripheral biomarkers of drug-target interaction and surrogate peripheral blood or tissue markers for drug efficacy within the CNS may well be established in animal models but will ultimately assist in dose-range finding and prediction of responders $v s$ nonresponders in human trials. Drug mechanisms of action will be better defined using transcript profiling both in animal models and in drug responders in clinical trials. Combination therapy with drugs that drive repair and preserve the integrity of axons and myelin need to be evaluated for their use in a chronic disease like MS as well as for their compatibility, safety, and efficacy when given with antiinflammatory drugs.

\section{ACKNOWLEDGEMENTS}

I express gratitude to Dr Bin Zhu, Dr Scot Styren, Kathleen McMonagle-Strucko, David Selk, and Claudine Pulicicchio for the generation of data with teriflunomide in models of EAE.

\section{DISCLOSURE/CONFLICT OF INTEREST}

The author declares that she is an employee of and has received income from Sanofi-Aventis. There are no additional financial holdings by the author that could be perceived as constituting a potential conflict of interest. The work described herein on teriflunomide was funded by Sanofi-Aventis.

\section{REFERENCES}

Adamo AM, Paez PM, Escobar Cabrera OE, Wolfson M, Franco PG, Pasquini JM et al (2006). Remyelination after cuprizone-induced demyelination in the rat is stimulated by apotransferrin. Exp Neurol 198: 519-529.

Anderson SA, Shukalial-Quandt J, Jordan EK, Arbab AS, Martin R, McFarland H et al (2004). Magnetic resonance imaging of labeled T-cells in a mouse model of multiple sclerosis. Ann Neurol 55: 654-659.

Armstrong RC, Dorn HH, Kufta CV, Friedman E, Dubois-Dalcq ME (1992). Preoligodendrocytes from adult human CNS. J Neurosci 12: 1538-1547.

Arnon R (1981). Experimental allergic encephalomyelitis-susceptibility and suppression. Immunol Rev 55: 5-30.

Atkinson S, Li Y-Q, Wong SC (2003). Changes in oligodendrocytes and myelin gene expression after radiation in the rodent spinal cord. Int $\mathrm{J}$ Radiat Oncol Biol Phys 57: 1093-1100

Barres BA, Hart IK, Coles HSR, Burne JF, Voyvodic JT, Richardson WD et al (1992) Cell death and control of cell survival in the oligodendrocyte lineage. Cell 70 31-46.

Bechtold DA, Kapoor R, Smith KJ (2004). Axonal protection using flecainide in experimental autoimmune encephalomyelitis. Ann Neurol 55: 607-616.

Beeton C, Wulff H, Barbaria J, Clot-Faybesse O, Pennington M, Bernard D et al (2001). Selective blockade of $T$ lymphocyte $K+$ channels ameliorates experi- 
mental autoimmune encephalomyelitis, a model for multiple sclerosis. Proc Natl Acad Sci USA 98: 13942-13947.

Benveniste EN, Merrill JE (1986). Stimulation of oligodendroglial proliferation and maturation by interleukin-2. Nature 321: 610-613.

Berger C, Hiestand P, Kindler-Baumann D, Rudin M, Rausch M (2006). Analysis of lesion development during acute inflammation and remission in the rat model of experimental autoimmune encephalomyelitis by visualization of macrophage infiltration, demyelination, and blood-brain barrier damage. NMR Biomed 19: 101-107.

Bernard CCA (1976). Experimental autoimmune encephalomyelitis in mice: genetic control of susceptibility. J Immunogenet 3: 263-274.

Blakemore WF, Franklin RJM (1991). Transplantation of glial cells into the CNS. Trends Neurosci 14: 323-327.

Blanchard AP, Friend SH (1999). Cheap DNA arrays-it's not all smoke and mirrors. Nat Biotechnol 17: 953.

Bo L, Dawson TM, Wesselingh S, Mork S, Choi S, King PA et al (1994). Induction of nitric oxide synthase in demyelinating regions of multiple sclerosis brains. Ann Neurol 36: 778-786.

Boullerne Al, Benjamins JA (2006). Nitric oxide synthase expression and nitric oxide toxicity in oligodendrocytes. Antiox Redox Signal 8: 967-980.

Brochet B, Deloire MSA, Touil T, Anne O, Caille JM, Dopusset V et al (2006). Early macrophage MRI of inflammatory lesions predicts lesion severity and disease development in relapsing EAE. Neuroimage 32: 266-274.

Brogi A, Strazza M, Melli M, Constantino-Ceccarini E (1997). Induction of intracellular ceramide by interleukin-1B in oligodendrocytes. J Cell Biochem 66: 532-541.

Brok HPM, Bauer J, Jonker M, Blezer E, Amor S, Bontrop RE et al (2001). Nonhuman primate models of multiple sclerosis. Immunol Rev 183: 173-185.

Brosnan CF, Battistini L, Raine CS, Dickson DW, Casadevall A, Lee SC (1994). Reactive nitrogen intermediates in human neuropathology: an overview. Dev Neurosci 16: 152-161.

Butzkueven $\mathrm{H}$, Zhang J-G, Soilu-Hanninen M, Hochrein H, Chionh F, Shipham KA et al (2002). LIF receptor signaling limits immune-mediated demyelination by enhancing oligodendrocyte survival. Nat Med 8: 613-619.

Casaccia-Bonnefil P (2000). Cell death in the oligodendrocyte lineage: a molecular perspective of life/death decisions in development and disease. Glia 29: 124-135.

Casaccia-Bonnefil P, Aibel L, Chao MV (1996). Central glial and neuronal populations display differential sensitivity to ceramide-dependent cell death. J Neurosci Res 43: 382-389.

Chakraborty G, Ziemba S, Drivas A, Ledeen RW (1997). Myelin contains neutral sphingomyelinase activity that is stimulated by tumor necrosis factor- $\alpha$. J Neurosci Res 50: 466-476.

Charles P, Hernandez MP, Stankoff B, Aigrot MS, Colin C, Rougon G et al (2000). Negative regulation of central nervous system myelination by polysialated-neural cell adhesion molecule. Proc Natl Acad Sci USA 97: 7585-7590.

Coman I, Barbin G, Charles P, Zalc B, Lubetzki C (2005). Axonal signals in the central nervous system myelination, demyelination, and remyelination. $J$ Neurol Sci 233: 67-71.

Copelman CA, Cuzner ML, Groome N, Diemel LT (2000). Temporal analysis of growth factor mRNA expression in myelinating rat brain aggregrate cultures: increments in CNTF, FGF-2, IGF-1, and PDGF-AA mRNA are induced by antibody-mediated demyelination. Glia 30: 342-351.

Dal Canto MC, Lipton HL (1976). Primary demyelination in Theiler's virus infection. Lab Invest 33: 626-637.

Dalal M, Kim S, Voskuhl RR (1997). Testosterone therapy ameliorates experimental autoimmune encephalomyelitis and induces a Thelper 2 bias in the autoantigenspecific T lymphocyte response. J Immunol 159: 3-6.

Davis MD, Clemens JJ, Macdonald TL, Lynch KR (2005). Sphingosine 1-phosphate analogs as receptor antagonists. J Biol Chem 280: 9833-9841.

Demerens C, Stankoff B, Logak M, Anglade P, Allinquant B, Couraud F et al (1996). Induction of myelination in the central nervous system by electrical activity. Proc Natl Acad Sci USA 93: 9887-9892.

Diem R, Sattler MB, Merkler D, Demmer I, Maier K, Stadelmann C et al (2005). Combined therapy with methylprednisolone and erythropoietin in a model of multiple sclerosis. Brain 128: 375-385.

Dousset V, Brochet B, Vital A, Gross C, Benazzouz A, Boullerne A et al (1995). Lysolecithin-induced demyelination in primates: preliminary in vivo study with MR and magnetization transfer. Am J Neuroradiol 16: 225-231.

Eccleston PA, Silberberg DH (1984). The differentiation of oligodendrocytes in serum-free hormone-supplemented medium. Dev Brain Res 16: 1-9.

Fernandez M, Giuliani A, Pirondi S, D'Intino G, Giardino L, Aloe L et al (2004). Thyroid hormone administration enhances remyelination in chronic demyelinating inflammatory disease. Proc Natl Acad Sci USA 101: 16363-16368.

Feurer C, Prentice DE, Cammisuli S (1985). Chronic relapsing experimental allergic encephalomyelitis in the Lewis rat. J Neuroimmunol 10: 159-166.
Floris A, Blezer ELA, Schreibelt G, Dopp E, van der Pol SMA, Schadee-Eestermans IL et al (2004). Blood-brain barrier permeability and monocyte infiltration in experimental allergic encephalomyelitis: a quantitative MRI study. Brain 127: 616-627.

Foster LM, Phan T, Verity AN, Bredesen D, Campagnoni AT (1993). Generation and analysis of normal and shiverer temperature-sensitive immortalized cell lines exhibiting phenotypic characteristics of oligodendrocytes at several stages of differentiation. Dev Neurosci 15: 100-109.

Fox RI, Herrmann ML, Frangou CG, Wahl GM, Morris RE, Strand V et al (1999). Mechanism of action for leflunomide in rheumatoid arthritis. Clin Immunol 93: 198-208.

Franco-Pons N, Torrente M, Colomina MT, Vilella E (2007). Behavioral deficits in the cuprizone-induced murine model of demyelination/remyelination. Toxicol Lett 169: $205-213$

Franklin RJM (2002). Why does remyelination fail in multiple sclerosis? Nat Rev $\mathbf{3}$ : $705-714$.

Franklin RJM, Blakemore WF (1995). Glial-cell transplantation and plasticity in the O-2A lineage-implications for CNS repair. Trends Neurosci 18: 151-156.

Fujiyoshi K, Tamada M, Nakamura M, Yamane J, Katoh H, Kitamure K et al (2007). In vivo tracing of neural tracts in the intact and injured spinal cord of marmosets by diffusion tensor tractography. J Neurosci 27: 11991-11998.

Gallo V, Zhou JM, McBain CJ, Wright P, Knutson PL, Armstrong RC (1996). Oligodendrocyte progenitor cell proliferation and lineage progression are regulated by glutamate receptor-mediated K+ channel block. J Neurosci 16: 2659-2670.

Genain GP, Hauser SL (2001). Experimental allergic encephalomyelitis in the new world monkey Callithrix jacchus. Immunol Rev 183: 159-172.

Gilson J, Blakemore WF (1993). Failure of remyelination in areas of demyelination produced in the spinal cord of old rats. Neuropathol Appl Neurobiol 19: 173-181.

Girard C, Bemelmans A-P, Dufour N, Mallet J, Bachelin C, Nait-Oumesmar B et al (2005). Grafts of brain-derived neurotrophic factor and neurotrophin 3transduced primate Schwann cells lead to functional recovery of the demyelinated mouse spinal cord. J Neurosci 25: 7924-7933.

Graca DL, Blakemore WF (1986). Delkayed remyelination in the rat spinal cord following ethidium bromide injection. Neuropathol Appl Neurobiol 12: 593-605.

Gregg C, Shikar V, Larsen P, Mak G, Chojnacki A, Yong VW et al (2007). White matter plasticity and enhanced remyelination in the maternal CNS. J Neurosci 27: 1812-1823.

Grinspan J, Wrabetz L, Kamholz J (1993). Oligodendrocyte maturation and myelin gene expression in PDGF-treated cultures from rat cerebral white matter. J Neurocytol 22: 322-333.

Guazzo EP (2005). A technique for producing demyelination of the rat optic nerves. J Clin Neurosci 12: 54-58.

Honmou O, Felts PA, Waxman SG, Kocsis JD (1996). Restoration of normal conduction properties in demyelinated spinal cord axons in the adult rat by transplantation of exogenous Schwann cells. J Neurosci 16: 3199-3208.

Honnegger $P$ (1985). Biochemical differentiation in serum-free aggregating brain cell cultures. In: Bottenstein JE, Sato G (eds). Cell Culture in Neurosciences. Plenum: New York. pp 223-243.

Hunter MIS, Nlemadim BC, Davidson DLW (1985). Lipid peroxidation production and antioxidant proteins in plasma and cerebrospinal fluid from multiple sclerosis patients. Neurochem Res 10: 1645-1652.

Husain J, Juurlink BHJ (1995). Oligodendroglial precursor cell susceptibility to hypoxia is related to poor ability to cope with reactive oxygen species. Brain Res 698: 86-94.

Ibanez C, Shields SA, El-Etr M, Baulieu E-E, Schumacher M, Franklin RJM (2004). Systemic progesterone administration results in a partial reversal of the ageassociated decline in CNS remyelination following toxin-induced demyelination in rats. Neuropathol Appl Neurobiol 30: 80-89.

Irvine K-A, Blakemore WF (2006). Age increases axon loss associated with primary demyelination in cuprizone-induced demyelination in C57BI/6 mice. J Neuroimmunol 175: 69-76.

Ishibashi T, Dakin KA, Stevens B, Lee PR, Kozlov SV, Stewart CL et al (2006). Astrocytes promote myelination in response to electrical impulses. Neuron 49: 823-832.

Issazadeh S, Lorentzen JC, Mustafa MI, Hojeberg B, Mussener A, Olsson T (1996). Cytokines in relspaing experimental autoimmune encephalomyelitis in DA rats: persistent mRNA expression of proinflammatory cytokines and absent expression of interleukin-10 and transforming growth factor- $\beta$. J Neuroimmunol 69: 103-115.

Jaillard C, Harrison S, Stankoff B, Aigrot MS, Calver AR, Duddy G et al (2005). Edg9/S1P5: an oligodendoglial receptor with dual function on process retraction and cell survival. J Neurosci 25: 1459-1469.

James T, Matzelle D, Bartus R, Hogan EL, Banik NL (1998). New inhibitors of calpain prevent degradation of cytoskeletal and myelin proteins in spinal cord in vitro. J Neurosci Res 51: 218-222. 
Jeffrey ND, Blakemore WF (1995). remyelination of mouse spinal cord axons demyelinated by local injection of lysolecithin. J Neurocytol 24: 775-781.

Jensen NA, Smith GM, Garvey JS, Shine HD, Hood L (1993). Cyclic AMP has a differentiative effect on an immortalized oligodendrocyte cell line. J Neurosci Res 35: 288-296.

Johnson AW, Land JM, Thompson EJ, Bolanos JP, Clark JB, Heales SJR (1995). Evidence for increased nitric oxide production in multiple sclerosis. Letter. J Neurol Neurosurg Psychiatry 58: 107.

Jordan CA, Friedrich Jr VL, de Ferra F, Weismiller DG, Holmes KV, Dubois-Dalcq M (1990). Differential exon expression in myelin basic protein transcripts during central nervous system (CNS) remyelination. Cell Mol Neurobiol 10: 3-18.

Kanwar JR, Kanwar RK, Krissansen GW (2004). Simultaneous neuroprotection and blockade of inflammation reverses autoimmune encephalomyelitis. Brain 127: 1313-1331.

Kappos L, Antel J, Comi G, Montalban X, O'Connor P, Polman CH, et al, FTY720 D2201 Study Group (2006). Oral fingolimod (FTY720) for relapsing multiple sclerosis. N Eng J Med 355: 1124-1140.

Kashima T, Tiu SN, Merrill JE, Vinters HV, Dawson G, Campagnoni AT (1993). Expression of oligodendrocyte-associated genes in cell lines derived from human gliomas and neuroblastomas. Cancer Res 53: 170-175.

Keirstead HS, Levine JM, Blakemore WF (1998). Response of the oligodendrocyte progenitor cell population (defined by NG2 labelling) to demyelination of the adult spinal cord. Glia 22: 161-170.

Knutson P, Ghiani CA, Zhou JM, Gallo V, McNain CJ (1997). K+ channel expression and cell proliferation are regulated by intracellular sodium and membrane depolarization in oligodendrocyte progenitor cells. J Neurosci 17: 2669-2682.

Kotter MR, Setzu A, Sim FJ, Van Rooijen N, Franklin RJM (2001). Macrophage depletion impairs oligodendrocyte remyelination following lysolecithin-induced demyelination. Glia 35: 204-212.

Lachapelle F, Avellana-Adalid V, Nait-Oumesmar B, Baron-Van Evercooren A (2002). Fibroblast growth factor-2 (FGF-2) and platelet-derived growth factor AB $\left(\mathrm{PDGF}_{\mathrm{AB}}\right)$ promote adult SVZ-derived oligodendrogenesis in vivo. Mol Cell Neurosci 20: 390-403.

Lalive PH, Menge T, Delarasse C, Della Gaspera B, Pham-Dinh D, Villoslada P et al (2006). Antibodies to native myelin oligodendrocyte glycoprotein are serologic markers of early inflammation in multiple sclerosis. Proc Natl Acad Sci USA 103: 2280-2285.

Larocca JN, Farooq M, Norton WT (1997). Induction of oligodendrocyte apoptosis by C2-ceramide. Neurochem Res 22: 529-534.

Lassmann H, Bruck W, Lucchinetti C, Rodriguez M (1997). Remyelination in multiple sclerosis. Mult Scler 3: 133-136.

Lorentzen JC, Issazadeh S, Storch M, Mustafa MI, Lassmann H, Linington C et al (1995). Protracted, relapsing and dmyelinating experimental autoimmune encephalomyelitis in DA rats immunized with syngeneic spinal cord and incomplete Freund's adjuvant. J Neuroimmunol 63: 193-205.

Loughlin AJ, Copelman CA, Hall A, Armer T, Young BC, Landon DN et al (1997). Myelination and remyelination of aggregate rat brain cultures enriched with macrophages. J Neurosci Res 47: 384-392.

Louis JC, Magal E, Muir D, Manthorpe M, Varon S (1992). CG-4, a new bipotential glial cell line from rat brain, is capable of differentiating in vitro into either mature oligodendrocytes or type-2 astrocytes. J Neurosci Res 31: 193-204.

Lubetzki C, Demerens C, Anglade P, Villarroya H, Frankfurter A, Lee VM-Y (1993). Even in culture, oligodendrocytes myelinate solely axons. Proc Natl Acad Sci USA 90: 6820-6824.

Ludwin SK (1978). Central nervous system demyelination and remyelination in the mouse: an ultrastructural study of cuprizone toxicity. Lab Invest 39: $597-612$

MacKenzie-Graham AJ, Mitrovic B, Smoll A, Merrill JE (1994). Differential sensitivity to nitric oxide in immortalized, cloned murine oligodendrocyte cell lines. Dev Neurosci 16: 162-171.

Mandala S, Hajdu R, Bergstrom J, Quackenbush E, Xie J, Milligan J et al (2002). Alteration of lymphocyte trafficking by sphingosine-1-phosphate receptor agonists. Science 296: 346-349.

Marmur R, Kessler JA, Zhu G, Gokhan S, Mehler MF (1998). Differentiation of oligodendroglial progenitors derived from cortical multipotent cells requires extrinsic signals including activation of gp130/LIF $\beta$ receptors. J Neurosci 18: 9800-9811.

Martel RP, Botros IW, Rounseville MP, Hinton JP, Staples RR, Morales DA et al (2002). Multiplexed screening assay for mRNA combining nuclease protection with luminescent array detection. Assay Drug Dev Technol 1: 61-71.

Mason JL, Suzuki K, Chaplin DD, Matsushima GK (2001). Interleukin-1 $\beta$ promotes repair of the CNS. J Neurosci 21: 7046-7052.

Mason JL, Toews A, Hostettler JD, Morell P, Suzuki K, Goldman JE et al (2004). Oligodendrocytes and progenitors become progressively depleted within chronically demyelinated lesions. Am J Pathol 164: 1673-1682.
Mason JL, Ye P, Suzuki K, D’Ercole AJ, Matsushima GK (2000). Insulin-like growth factor- 1 inhibits mature oligodendrocyte apoptosis during primary demyelination. J Neurosci 20: 5703-5708.

Matsushima GK, Morell P (2001). The neurotoxicant, cuprizone, as a model to study demyelination and remyelination in the central nervous system. Brain Pathol 11 $107-116$.

Matute C, Alberdi W, Domercq M, Perez-Cerda F, Perez-Samartin A, SanchezGomez MV (2001). The link between excitotoxic oliogodendroglial death and demyelinating diseases. Trends Neurosci 24: 224-230.

McCarthy M, deVellis J (1980). preparation of separate astroglial and oligodendroglial cell cultures from rat cerebral tissues. J Cell Biol 85: 890-902.

Merkler D, Boretius S, Stadelmann C, Ernsting T, Michaelis T, Frahm J et al (2005). Multicontrast MRI of remyelination in the central nervous system. NMR Biomed 18: $395-403$.

Merrill JE, Ignarro LJ, Sherman MP, Melinek J, Lane TE (1993). Microglial cell cytotoxicity of oligodendrocytes is mediated through nitric oxide. $\mathrm{J} / \mathrm{mm}$ mol $\mathbf{1 5}$ 2123-2141.

Merrill JE, Matsushima K (1988). Production and response to interleukin 1 by cloned human oligodendroglioma cell lines. J Biol Regul Homeo Agents 2: 77-86.

Merrill JE, Scolding NJ (1999). Mechanisms of damage to myelin and oligodendrocytes and their relevance to disease. Neuropathol Appl Neurobiol 25 : 435-458.

Mi S, Hu B, Hahm K, Luo Y, Hui ESK, Yuan Q et al (2007). LINGO-1 antagonist promotes spinal cord remyelimation and axonal integrity in MOG-induced experimental autoimmune encephalomyelitis. Nat Med 13: 1228-1233.

Miron VE, Jung CG, Kim HJ, Kennedy TE, Soliven B, Antel JP (2008). FTY720 modulates human oligodendrocyte progenitor process extension and survival. Ann Neurol 63: 61-71.

Miron VE, Rajasekharan S, Jarjour AA, Zamvil SS, Kennedy TE, Antel JP (2007). Simvastatin regulates oligodendroglial process dynamics and survival. Glia $\mathbf{5 5}$ 130-143

Mitrovic B, Ignarro LJ, Montestruque S, Smoll A, Merrill JE (1994). Nitric oxide as a potential pathological mechanism in demyelination: its differential effects on primary glial cells in vitro. Neuroscience 61: 575-585.

Mitrovic B, Ignarro LJ, Vinters HV, Akers M-A, Schmid I, Uittenbogaart C et al (1995). Nitric oxide induces necrotic but not apoptotic cell death in oligodendrocytes. Neuroscience 65: 531-539.

Mitrovic B, Parkinson J, Merrill JE (1996). An in vitro model of oligodendrocyte destruction by nitric oxide and its relevance to multiple sclerosis. Methods: Comp Methods Enzymol 10: 501-513.

Murray K, Dubois-Dalca M (1997). Emergence of oligodendrocytes from human neural spheres. J Neurosci Res 50: 146-156.

Nicolay DJ, Doucette JR, Nazarali AJ (2007). Transcriptional control of oligodendrogenesis. Glia 55: 1287-1299.

Nunes MC, Roy NS, Keyoung HM, Goodman RR, McKhann II G, Jiang L et al (2003). Identification and isolation of multipotential neural progenitor cells from the subcortical white matter of the adult human brain. Nat Med 9 : 439-447.

O'Connor PW, Li D, Freedman MS, Bar-Or A, Rice GPA, Confavreux C et al (2006). A phase II study of the safety and efficacy of teriflunomide in multiple sclerosis with relapses. Neurology 66: 894-900.

Offner $\mathrm{H}$ (2004). Neuroimmunoprotective effects of estrogen and derivatives in experimental autoimmune encephalomyelitis: therapeutic implications for multiple sclerosis. J Neurosci Res 78: 603-624.

Ohori Y, Tamamoto S-I, Nagao M, Sugimori M, Yamamoto N, Nakamura K et al (2006). Growth factor treatment and genetic manipulation stimulate neurogenesis and oligodendrogenesis by endogenous neural progenitors in the injured adult spinal cord. J Neurosci 26: 11948-11960.

Okano H, Sakaguchi M, Onki K, Suzuki N, Sawamoto K (2007). Regeneration of the central nervous system using endogenous repair mechanisms. I Neurochem 102: $1459-1465$.

Otero GC, Merrill JE (1997). Response of human oligodendrocytes to interleukin-2. Brain Behav Immun 11: 24-38.

Oudega M, Xu XM, Guenard V, Kleitman N, Bunge MB (1997). A combination of insulin-like growth factor-I and platelet-derived growth factor enhances myelination but diminishes axonal regeneration into Schwann cell grafts in the adult rat spinal cord. Glia 19: 247-258.

Patneau DK, Wright PW, Winters C, Mayer ML, Callo V (1994). Glial cells of the oligodendrocyte lineage express both kainate- and AMPA-preferring subtypes of glutamate receptor. Neuron 12: 357-371.

Pfeiffer SE, Warrington AE, Bansal R (1993). The oligodendrocyte and it many processes. Trends Cell Biol 3: 191-197.

Pluchino S, Quattrini A, Brambilla E, Gritti A, Salani G, Dina G et al (2003). Injection of adult neurospheres induces recovery in a chronic model of multiple sclerosis. Nature 422: 688-694. 
Prineas JW (1985). The neuropathology of multiple sclerosis. In: Vincken PJ, Bruyn GW, Klawans HL (eds). Demyelinating Diseases. Elsevier Science: Amsterdam, pp 213-257.

Prineas JW, Barnard RO, Kwon EE, Sharer LR, Cho E-S (1993). Multiple sclerosis: remyelination of nascent lesions. Ann Neurol 33: 137-151.

Prineas JW, Connell F (1979). Remyelination in multiple sclerosis. Ann Neurol 5: 22-31.

Prineas JW, Kwon EE, Cho E-S, Sharer LR (1984). Continual breakdown and regeneration of myelin in progressive multiple sclerosis. Ann NY Acad Sci 436: 11-32.

Prineas JW, Kwon EE, Goldenberg PZ, Ilyas AA, Quarles RH, Benjamins JA et al (1989). Multiple sclerosis: oligodendrocyte proliferation and differentiation in fresh lesions. Lab Invest 61: 489-503.

Raible DW, McMorris FA (1989). Cyclic AMP regulates the rate of differentiation of oligodendrocytes without changing the lineage commitment of their progenitors. Dev Biol 133: 437-446.

Raine CS (1997). The Norton Lecture: a review of the oligodendrocyte in the multiple sclerosis lesion. J Neuroimmunol 77: 135-152.

Raine CS, Barnett LB, Brown A, Behar T, McFarlin DE (1980). Neuropathology of experimental allergic encephalomyelitis in inbred strains of mice. Lab Invest 43 : $150-157$.

Raine CS, Wu E (1993). Multiple sclerosis: remyelination in acute lesions. $\checkmark$ Neuropathol Exp Neurol 52: 199-204.

Roy NS, Wang S, Harrison-Restelli C, benraiss A, Fraser FA, Gravel M et al (1999). Identification, isolation, and promoter-defined separation of mitotic oligodendrocyte progenitor cells from the adult human subcortical white matter. J Neurosci 19: 9986-9995

Saxe JP, Wu H, Kelly TK, Phelps ME, Sun YE, Kornblum HI et al (2007). A phenotypic small-molecule screen identifies an orphan ligand-receptor pair that regulates neural stem cell differentiation. Chem Biol 14: 1019-1030.

Scolding NJ, Compston DA (1995). Growth factors fail to protect rat oligodendrocytes against humoral injury in vitro. Neurosci Lett 183: 75-78.

Selmaj K, Brosnan CF, Raine CS (1991). Colocalization of lymphocytes bearing gamma delta T-cell receptor and heat shock protein hsp65+ oligodendrocytes in multiple sclerosis. Proc Natl Acad Sci USA 88: 6452-6456.

Selmaj K, Brosnan CF, Raine CS (1992). Expression of heat shock protein-65 by oligodendrocytes in vivo and in vitro: implications for multiple sclerosis. Neurology 42: 795-800.

Sergott RC, Brown MJ, Silberberg DH (1985). Remyelination follows antibodyinduced central nervous system demyelination. Ann Neurol 20: 94-98.

Sim FJ, Lang JK, Waldau B, Roy NS, Schwartz TE et al (2006). Complementary patterns of gene expression by human oligodendrocyte progenitors and their environment predict determinants of progenitor maintenance and differentiation. Ann Neurol 59: 763-779.

Sim FJ, Zhao C, Penderis J, Franklin RJM (2002). The age-related decrease in CNS remyelination efficiency is attributable to an impairment of both oligodendrocyte progenitor recruitment and differentiation. J Neurosci 22: 2451-2459.

Smorodchenko A, Wuerfel J, pohl EE, Vogt J, Tysiak E, Glumm R et al (2007). CNSirrelevant T-cells enter the brain, cause blood-brain barrier disruption but no glial pathology. Eur J Neurosci 26: 1387-1398.

Sperber BR, McMorris FA (2001). Fyn tyrosine kinase regulates oligodendroglial cell development but is not required for morphological differentiation of oligodendrocytes. J Neurosci Res 63: 303-312.

Stangel M (2004). Remyelinating and neuroprotective treatments in multiple sclerosis. Expert Opin Investig Drugs 13: 331-347.

Stevens B, Porta S, Haak LL, Gallo V, Fields RD (2002). Adenosine: a neuron-glial transmitter promoting myelination in the CNS in response to action potentials. Neuron 36: 855-868.
Takao T, Flint N, Lee L, Ying X, Merrill J, Chandross KJ (2004). 17beta-estradiol protects oligodendrocytes from cytotoxicity induced cell death. J Neurochem 89 : 660-673.

Tanaka K, Nogawa S, Suzuki S, Dembo T, Kosakai A (2003). Upregulation of oligodendrocyte progenitor cells associated with restoration of mature oligodendrocytes and myelination in peri-infarct area in the rat brain. Brain Res 989: 172-179.

Thorburne SK, Juurlink BHJ (1996). Low glutathione and high iron govern the susceptibility of oligodendroglial precursors to oxidative stress. J Neurochem 67 : 1014-1022.

Tiwari-Woodruff S, Morales LBJ, Voskuhl RR (2007). Differential neuroprotective and anti-inflammatory effects of estrogen receptor (ER $\alpha$ and $E R \beta)$ ligand treatment. Proc Natl Acad Sci USA 104: 14813-14818.

Toman RE, Payne SG, Watterson KR, Maceyka M, Lee NH, Milstein S et al (2004). Differential activation of sphingosine-1-phosphate receptors modulates NGFinduced neurite extension. J Cell Biol 166: 381-392.

Tosic M, Torch S, Comte V, Dolivo M, Honegger P, Matthieu J-M (1992). Triiodothyronine has diverse and multiple stimulating effects on expression of the major myelin protein genes. J Neurochem 59: 1770-1777.

Touil T, Deloire-Grassin MS, Vital C, Petry KG, Brochet B (2001). In vivo damage of CNS myelin and axons induced by peroxynitrite. Neuroreport 12: 3637-3644.

Vartanian T, Li Y, Zhao M, Stefansson K (1995). Interferon-gamma-induced oligodendrocyte cell death: implications for the pathogenesis of multiple sclerosis. Mol Med 1: 732-743.

Verity AN, Bredesen D, Vonderscher C, Handley WW, Campagnoni AT (1993). Expression of myelin protein genes and myelin components in an oligodendrocyte cell line conditionally immortalized with a temperature sensitive retrovirus. J Neurochem 60: 577-587.

Wang C, Pralong WF, Schultz MF, Rougon G, Aubry JM, Pagliusi S et al (1996). Functional $N$-methyl-D-aspartate receptors in O-2A glial precursor cells: a critical role in regulating polysialic acid-neural cell adhesion molecule expression and cell migration. J Cell Biol 135: 1565-1581.

Webster HD (1997). Growth factors and myelin regeneration in multiple sclerosis. Mult Scler 3: 113-120.

Wilson HC, Onischke C, Raine CS (2003). Human oligodendrocyte precursor cells in vitro: phenotypic analysis and differential response to growth factors. Glia 44: 153-165.

Woodruff RH, Franklin RJM (1999). Demyelination and remyelination of the caudal cerebellar peduncle of adult rats following stereotaxic injections of lysolecithin, ethidium, bromide, and complement/anti-galactocerebroside. Glia 25: 216-228.

Wuerfel J, Tysiak E, Prozorovski T, Smyth M, Mueller S, Schnorr J et al (2007). Mouse model mimics multiple sclerosis in the clinico-radiological paradox. Eur $J$ Neurosci 26: 190-198.

Yang H, Lu P, McKay HM, Bernot T, Keirstead H, Steward O et al (2006). endogenous neurogenesis replaces oligodendrocytes and astrocytes after primate spinal cord injury. J Neurosci 26: 2157-2166.

Yoshioka A, Hardy M, Younkin DP, Grinspan JB, Stern JL, Pleasure D (1995). Alpha-amino-3-hydroxy-5-methyl-4-isoxazolepropionate (AMPA) receptors mediate excitotoxicity in the oligodendroglial lineage. I Neurochem 64: 2442-2448.

Yoshioka A, Shimizu Y, Hirose G, Kitasato H, Pleasure D (1998). Cyclic AMPelevating agents prevent oligodendroglial excitotoxicity. J Neurochem 70: 2416-2423.

Zhang Y, Taveggia C, Melendez-Vasquez C, Einheber S, Raine CS, Salzer JL et al (2006). Interleukin-11 potentiates oligodendrocyte survival and maturation, and myelin formation. J Neurosci 26: 12174-12185.

Zhang Z, Cerghet M, Mullins C, Williamson M, Bessert D, Skoff R (2004). Comparison of in vivo and in vitro subcellular localization of estrogen receptors $\alpha$ and $\beta$ in oligodendrocytes. J Neurochem 89: 674-684. 